\title{
PENGEMBANGAN MODUL PEMBELAJARAN KIMIA BERORIENTASI CHEMOENTREPRENEURSHIP (CEP) PADA POKOK BAHASAN SENYAWA TURUNAN ALKANA KELAS XII SMA/MA
}

Siti Rahmi Afwa*, Abdullah, Roza Linda

Program Studi Pendidikan Kimia FKIP Universitas Riau

Email: sitirahmiafwa15@gmail.com

\begin{abstract}
The research of development of learning module oriented chemoentrepreneurship (cep) on the subject matter alkane derived compounds for $3^{\text {rd }}$ grade of senior high school is an innovative development of teaching materials in accordance with the demands of the 2013 curriculum that demands the life skills of learners. The research was designed by research and development (R \& D) design with Plomp design research. Generally, the stages of research by using Plomp model includes the initial investigation phase, design phase, realization/ construction phase, trial validation and revise phase and also implementation phase. The development of chemoentrepreneurship (cep) oriented alkane derived compounds module in the topic of alkane derived compounds was only done until trial validation and revision. The aspects of the assessment which aspects self-instructional, aspects self-contained, aspects stand alone, aspects adaptive, aspects user friendly, aspects chemoentrepreneurship (CEP), aspects pedagogic and aspects gradability that are on the valid criteria with totally percentage score $92,77 \%$. User response scores by teachers and learners respectively are 93,94 and 93.33\% with very good criteria.
\end{abstract}

Key Words: Module, Chemoentrepreneurship, Alkane Derived Compounds, Plomp Design Research

\begin{abstract}
Abstrak
Penelitian pengembangan modul senyawa turunan alkana berorientasi chemoentrepreneurship pada pokok bahasan senyawa turunan alkana untuk kelas XII SMA/MA merupakan suatu inovasi pengembangan bahan ajar sesuai dengan tuntutan kurikulum 2013 yaitu life skill peserta didik. Penelitian ini dirancang menggunakan desain penelitian dan pengembangan $(R \& D)$ dengan model pengembangan Plomp. Secara garis besar, tahapan penelitian dengan menggunakan model Plomp meliputi fase
\end{abstract}


investigasi awal; fase perancangan; fase realisasi/konstruksi, dan fase validasi, uji coba dan revisi, dan fase implementasi. Pengembangan modul berorientasi chemoentrepreneurship pada pokok bahasan Senyawa Turunan Alkana hanya dilakukan sampai fase validasi, uji coba dan revisi. Hasil analisis lembar valiadasi yang berupa penilaian dan saran oleh tim validator meliputi beberapa aspek yaitu meliputi aspek self-instructional, aspek self-contained, aspek stand alone, aspek adaptive, aspek user friendly, aspek chemoentrepreneurship (CEP), aspek pedagogik dan aspek kegrafisan. Kuesienor respond pengguna meliputi guru dan peserta didik. Modul dinyatakan valid dengan skor keseluruhan validasi $92,77 \%$. Skor respon pengguna yaitu guru dan peserta didik berturut turut adalah adalah 93,94\% dan 93,33\% dengan kriteria sangat baik.

Kata Kunci:, Modul, Chemoentrepreneurship (CEP), Senyawa Turunan Alkana, Model Pengembangan Plomp

\section{PENDAHULUAN}

Undang Undang RI No.20 Tahun 2003 Bab II Pasal 3 tentang Sistem Pendidikan Nasional, menyatakan bahwa pendidikan nasional berfungsi mengembangkan kemampuan dan membentuk watak serta peradaban bangsa yang bermartabat dalam rangka mencerdaskan kehidupan bangsa, bertujuan untuk berkembangnya potensi peserta didik, agar menjadi manusia yang beriman dan bertakwa kepada Tuhan Yang Maha, berakhlak mulia, sehat, berilmu, cakap, kreatif, mandiri, dan menjadi warga negara yang yang demokratis serta bertanggung jawab. Perkembangan pendidikan pada hakikatnya mencerdaskan dan meningkatkan kualitas sumber daya manusia. hal ini dapat tercapai melalui pembelajaran. Pembelajaran sains pada hakikatnya terdiri atas produk, proses, dan sikap yang menuntut peserta didik melakukan penemuan dan pemecahan masalah Widyaningrum (dalam Wikhdah, 2015). Kurikulum merupakan salah satu unsur yang bisa memberikan kontribusi signifikan untuk mewujudkan perkembangan kualitas potensi peserta didik (Bintari, 2014).

Kurikulum 2013 merupakan bentuk pengembangan kurikulum yang menekankan pada pengembangan produktif, kreatif, inovatif, dan sikap afektif peserta didik melalui penguatan sikap, keterampilan, dan pengetahuan yang terintegrasi pada proses pembelajaran. Pelaksanaan kurikulum 2013 pada pembelajaran masih mengalami beberapa kendala, terutama pada mata pelajaran kimia. Pembelajaran kimia di SMA 
belum menekankan pada pemberian pengalaman belajar melalui penggunaan dan pengembangan keterampilan proses. Arti sebenarnya dari belajar kimia adalah upaya untuk mengetahui berbagai fenomena atau gejala alam agar mendapatkan sesuatu yang bermanfaat bagi kehidupan manusia. Paradigma pendidikan ini didesain untuk mengembangkan kompetensi-kompetensi yang sesuai dengan perkembangan kebutuhan seperti pendidikan karakter, metodologi pembelajaran aktif, keseimbangan soft skill dan hard skill, serta kewirausahaan yang belum diakomodasikan dengan baik pada kurikulum.

Pendidikan berbasis kewirausahaan adalah pendidikan yang menerapkan prinsipprinsip dan metodologi ke arah internalisasi nilai-nilai peserta didiknya melalui kurikulum yang terintegrasi dengan perkembangan yang terjadi baik di lingkungan sekolah maupun lingkungan masyarakatnya serta penggunaan model dan strategi pembelajaran yang relevan dengan tujuan pembelajaran itu sendiri (Anwar dalam Agus Winarno, 2009).

Tabel1. Contoh Produk Kewirausahaan yang Berhubungan dengan Mata Pelajaran Kimia

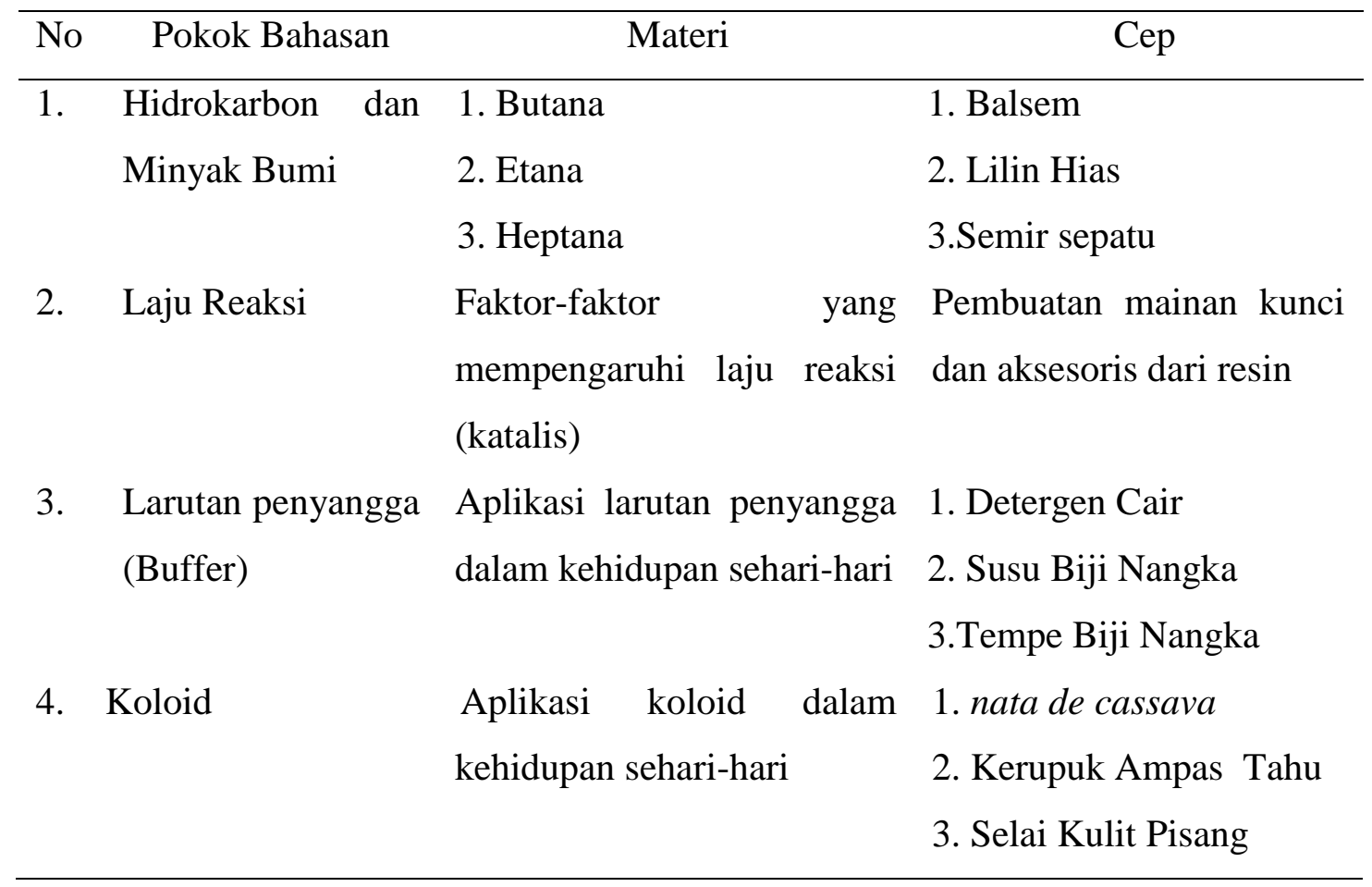

Guru memiliki peranan sebagai tenaga profesional yang bertugas merencanakan dan melaksanakan proses pembelajaran, menilai hasil pembelajaran, melakukan 
pembimbingan dan pelatihan. Guru mempunyai 4 kompetensi yang mumpuni, yaitu kompetensi pedagogik, profesional, sosial dan kepribadian. Agar kompetensi guru tetap terjaga dan meningkat. Guru mempunyai kewajiban untuk selalu memperbaharui dan meningkatkan kompetensinya melalui kegiatan pengembangan keprofesian berkelanjutan sebagai esensi pembelajaran seumur hidup. Guru dituntut kreatif dan inovatif dalam proses pembelajaran dikelas (Herliani, 2016).

Berdasarkan hasil wawancara dengan guru kimia SMAN 2 Pekanbaru guru masih menggunakan bahan ajar yang tinggal pakai, tinggal beli, instan serta tanpa upaya merencanakan, menyiapkan dan menyusun sendiri. Bahan ajar yang digunakan guru adalah buku paket dan LKPD. Sumber belajar yang digunakan guru juga tidak berbasis kewirausahaan.

Berangkat dari masalah tersebut, guru dituntut untuk dapat mempersiapkan bahan ajar sebelum pembelajaran dan selain itu, bahan ajar yang dipersiapkan guru idealnya memiliki pendekatan kewirausahaan. Mengingat mata pelajaran kimia memiliki aplikasi yang banyak dalam kehidupan sehari-hari. Bahan ajar yang dapat digunakan oleh guru yaitu berupa modul yang berorientasi kewirusahaan (chemoentrepreneurship). Menurut Daryanto (2013), modul merupakan salah satu bentuk bahan ajar yang dikemas secara utuh dan sistematis, didalamnya memuat seperangkat pengalaman belajar yang terencana dan didesain untuk membantu peserta didik menguasai tujuan belajar yang spesifik. CEP adalah suatu pendekatan pembelajaran kimia yang mengajak peserta didik untuk mempelajari proses pengolahan suatu bahan menjadi produk yang bermanfaat, bernilai ekonomi, dan menumbuhkan semangat berwirausaha (Supartono, 2009).

Berdasarkan paparan diatas, maka dilakukan penelitian pengembangan modul pembelajaran kimia berorientasi chemoentrepreneurship (CEP) pada pokok bahasan senyawa turunan alkana kelas XII SMA/MA.

\section{METODE PENELITIAN}

Penelitian dilaksanakan di Program Studi Pendidikan Kimia FKIP Universitas Riau Pekanbaru.. Pengembangan modul berorientasi chemoentrepreneurship (CEP) pada pokok bahasan senyawa turunan alkana untuk kelas XII SMA/MA dirancang menggunakan desain penelitian dan pengembangan (Research and Development $(R \& D)$ 
dengan model prosedural. Desain penelitian dan pengembangan (Research and Development $(R \& D)$ dalam pendidikan merupakan sebuah desain pengembangan untuk merancang produk pendidikan yang kemudian secara sistematis dievaluasi, diuji di lapangan, dan disempurnakan hingga memenuhi kriteria tertentu .

Modul berorientasi chemoentrepreneurship (CEP) pada pokok bahasan senyawa turunan alkana untuk kelas XII SMA/MA dikembangkan menggunakan model pengembangan Plomp yang terdiri dari fase investigasi awal, fase desain, fase realisasi/konstruksi, dan fase validasi, uji coba dan revisi, dan fase implementasi (Rochmad, 2012). Fase implementasi tidak dilakukan karena tujuan penelitian dibatasi hingga diperolehnya luaran berupa produk yang valid berdasarkan aspek subtansi materi, desain pembelajaran, tampilan (komunikasi visual) dan pemanfaatan modul cetak.

Pengumpulan data terkait validitas dan respon pegguna terhadap Modul berorientasi chemoentrepreneurship (CEP) pada pokok bahasan senyawa turunan alkana untuk kelas XII SMA/MA diperoleh pada fase validasi, uji coba dan revisi menggunakan instrumen penelitian berupa lembar validasi oleh tiga orang validator beserta rubrik dan kuesioner respon pengguna oleh guru dan peserta didik.

Data yang dikumpulkan kemudian dianalisis dengan teknik analisis tertentu. Analisis validitas menggunakan rumusan:

$$
P=\frac{f}{N} \times 100 \%
$$

Keterangan:

$$
\begin{aligned}
& P=\text { Persentse skor }(\%) \\
& F=\text { Jumlah skor rata-rata yang diperoleh } \\
& N=\text { Jumlah skor keseluruhan }
\end{aligned}
$$

Persentase yang diperoleh kemudian dikonversi menjadi nilai kualitatif dengan kriteria validitas pada Tabel 1 . 
Tabel 1. Kriteria Validitas

\begin{tabular}{cc}
\hline Persentase $(\%)$ & Kriteria \\
\hline $75,00-100$ & Valid \\
$50,00-74,99$ & Cukup Valid \\
$25,00-49,99$ & Kurang Valid \\
$0,00-24,99$ & Tidak Valid \\
\hline
\end{tabular}

Analisis respon guru menggunakan skala empat pilihan Likert dengan pedoman penskoran pada Tabel 2.

Tabel 2. Pedoman Penskoran Respon Pengguna

\begin{tabular}{cc}
\hline Persentase $(\%)$ & Kriteria \\
\hline $75,00-100$ & Dapat digunakan tanpa revisi \\
$50,00-74,99$ & Dapat digunakan dengan sedikit revisi \\
$25,00-49,99$ & Dapat digunakan dengan banyak revisi \\
$0,00-24,99$ & Tidak dapat digunakan \\
\hline
\end{tabular}

(Widoyoko, 2017).

Analisis respon peserta didik menggunakan skala guttman dengan dua rentang penilaian, yaitu skor 1 untuk jawaban 'Ya' dan 0 untuk jawaban 'Tidak'. Jika rata-rata nilai respon peserta didik yang didapat $<50 \%$, maka modul dinyatakan dapat digunakan dengan baik dan kebalikannya.

\section{HASIL DAN PEMBAHASAN}

Penelitian pengembangan ini menghasilkan suatu produk berupa Modul berorientasi chemoentrepreneurship (CEP) pada pokok bahasan senyawa turunan alkana untuk kelas XII SMA/MA. Berikut pemaparan hasil dan pembahasan dari setiap fase pengembangan yang telah dilakukan.

\section{Fase Investigasi Awal}

\section{Analisis Ujung Depan}

Informasi dan data yang diperoleh dari analisis ujung depan adalah terkait bahan ajar, materi pembelajaran dan ketertarikan peserta didik. Bahan ajar yang umum digunakan dalam proses pembelajaran adalah bahan ajar cetak yang berupa buku teks, 
LKPD. Materi pembelajaran kimia yang dianggap sulit salah satunya adalah materi senyawa turunan alkana, karena materi ini menuntut adanya pemahaman konsep sehingga Peserta didik tidak tertarik terhadap pokok bahasan tersebut.

Analisis ujung depan terhadap berbagai literatur relevan, diperoleh infromasi bahwa bahan ajar yang sesuai dengan tuntutan kurikulum 2013 adalah bahan ajar berorientasi chemoentrepreneurship. Tidak semua lulusan SMA dapat melanjutkan keperguruan tinggi sehingga dibutuhkanlah bahan ajar yang dapat menuntut life skill peserta didik.

\section{Analisis Peserta Didik}

Peserta didik yang mempelajari materi senyawa turunan alkana pada umumnya berusia 17-18 tahun dan berdasarkan teori perkembangan kognitif Piaget, pada usia ini peserta didik mendekati efisiensi intelektual yang maksimal, sehingga dibutuhkan bahan ajar yang dapat menarik minat peserta didik sehingga perkembangan kognitif peserta didik dapat berjalan optimal.

\section{Analisis Materi}

Materi yang dipih untuk pengembangan modul adalah materi senyawa turunan alkana. Hasil analisis materi berupa konsep-konsep materi senyawa turunan alkana.

\section{Analisis Kompetensi}

Materi senyawa turunan alkana merupakan salah satu materi pembelajaran kimia yang terdapat pada kompetensi dasar 3.9 dan 4.9 pada silabus mata pelajaran kimia SMA/MA oleh Kementrian Pendidikan dan Kebudayaan (2016), sehingga berlandas dari kompetensi dasar tersebut, diperolehlah rumusan tujuan pembelajaran yang harus dicapai oleh peserta didik.

\section{Fase Desain}

Desain prototipe yang memuat konten-konten1) judul modul, 2) petunjuk penggunaan modul, 3) tujuan pembelajaran, 4) materi modul, 5) aktivitas peserta didik dalam modul, 6) tes formatif dan evaluasi, 7) tugas/latihan dan 8) sumber/daftar pustaka modul. Desain instrumen berupa kisi-kisi lembar validasi dan desain kuesioner respon pengguna oleh guru dan peserta didik.

\section{Fase Realisasi/Konstruksi}

Realisasi prototipe berupa modul berorientasi chemoentrepreneurship senyawa turunan alkana yang telah sesuai dengan hasil analisis yang telah dilakukan, 
karakteristik dan stuktur modul, konten-konten chemoentrepreneurship, serta komponen penilaian bahan ajar. Modul berorientasi chemoentrepreneurship senyawa turunan alkana telah dirancang sedemikian rupa sehingga dihasilkan modul yang dapat menumbuhkan semangat kewirausahaan peserta didik . Modul senyawa turunan alkana berorientasi chemoentrepreneurship (CEP) tersaji dalam gambar 1.
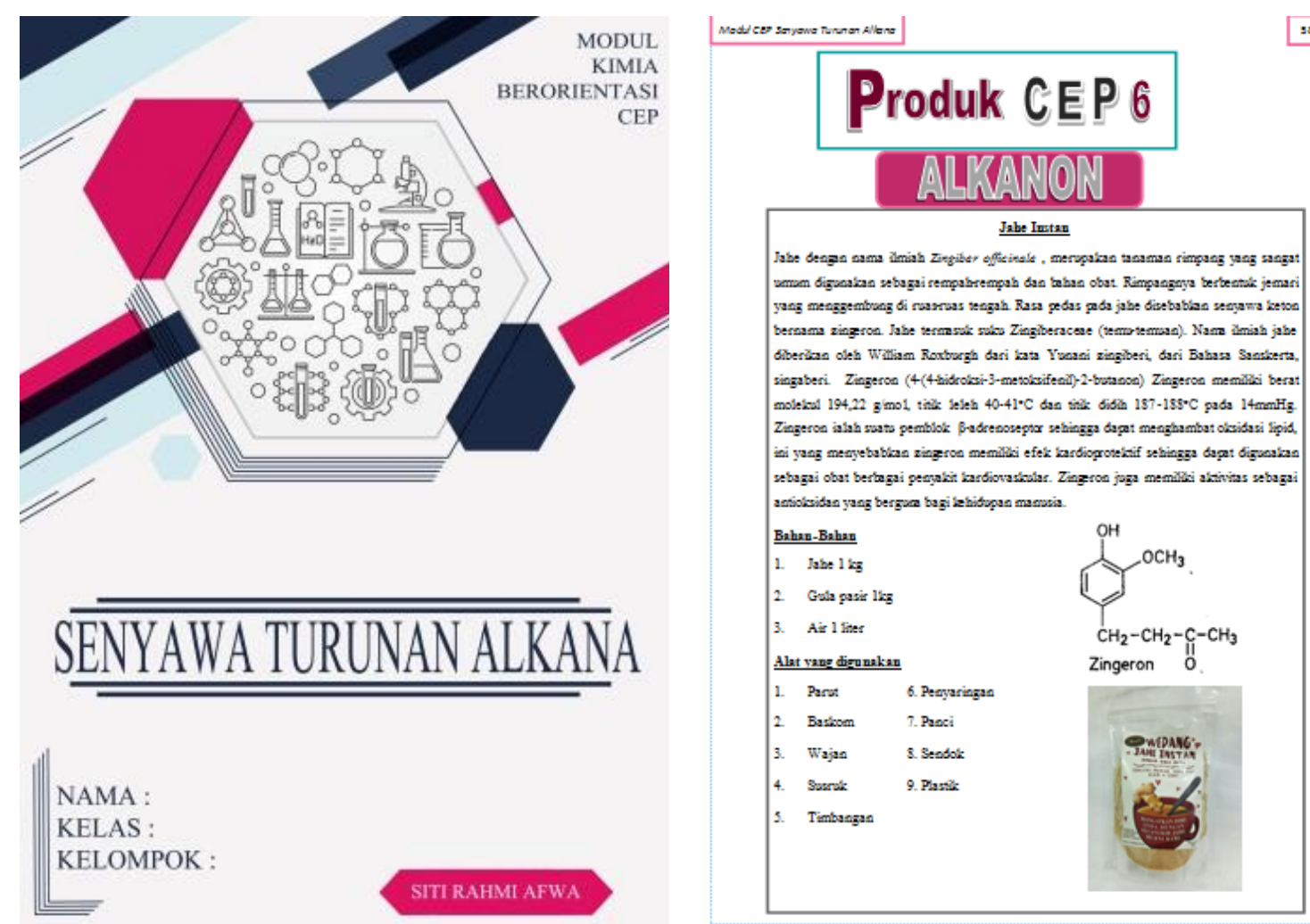

Gambar 1. Desain modul senyawa turunan alkana berorientasi chemoentrepreneurship (CEP)

Realisasi dari desain instrumen menghasilkan lembar validasi oleh validator yang merujuk pada panduan pengembangan bahan ajar oleh Direktorat Pembinaan SMA (2010) dan kuesioner respon pengguna oleh guru dan peserta didik yang dikonstruksi sedemikian rupa dari penelitian sebelumnya sesuai dengan kebutuhan penelitian.

\section{Fase Validasi, Uji Coba dan Revisi}

Validasi bertujuan untuk memperoleh penilaian dan saran terhadap modul berorientasi chemoentrepreneurship senyawa turunan alkana oleh tim validator yang berjumlah tiga orang yaitu 2 orang Dosen pendidikan Kimia FKIP Universitas Riau dan 
1 orang Dosen Pendidikan Kimia Fakultas Tarbiyah dan Keguruan Universitas Islam Negeri Sultan Sarif Kasim Riau. Hasil analisis validasi masing-masing aspek meliputi:

1. Aspek self-instructional (bahan ajar mandiri) Aspek Self-instructional memiliki 10 komponen penilaian Skor rata-rata validasi aspek self-instructional adalah 92,50\%. Berdasarkan kriteria validitas modul maka kriteria kelayakan analisis persentase nilai $92,50 \%$ terletak pada rentang $75 \%$ $100 \%$ dengan kategori valid.

2. Aspek self-contained (utuh)

Aspek Self-contained memiliki 2 komponen penilaian Skor rata-rata validasi aspek self-contained adalah 95,83\%. Berdasarkan kriteria validitas modul, maka kriteria kelayakan analisis persentase nilai 95,83\% terletak pada rentang 75\% - 100\% dengan kategori valid.

3. Aspek stand alone (Berdiri Sendiri)

Aspek Stand alone memiliki 2 komponen penilaian Skor rata-rata validasi aspek stand alone adalah 95,83\%. Berdasarkan kriteria validitas modul maka kriteria kelayakan analisis persentase nilai 95,83\% terletak pada rentang 75\% - 100\% dengan kategori valid.

4. Aspek adaptive (Mengikuti Perkembangan Ilmu Pengetahuan)

Apek Adaptive memiliki 2 komponen penilaian Skor rata-rata validasi aspek adaptive adalah 95,83\%. Berdasarkan kriteria validitas modul maka kriteria kelayakan analisis persentase nilai $95,83 \%$ terletak pada rentang $75 \%$ - $100 \%$ dengan kategori valid.

5. Aspek user friendly (Mudah di Pahami)

Aspek User friendly memiliki 5 komponen penilaian. Skor rata-rata validasi aspek user friendly adalah $88,33 \%$. Berdasarkan kriteria validitas modul maka kriteria kelayakan analisis persentase nilai $88,33 \%$ terletak pada rentang $75 \%-100 \%$ dengan kategori valid.

6. Aspek Chemoentrepreneurship (Kewirausahaan)

Aspek cehmoentrepreneurship memiliki 4 komponen penilaian Skor rata-rata validasi aspek chemoentrepreneurship adalah 100\%. Berdasarkan kriteria validitas modul maka kriteria kelayakan analisis persentase nilai $100 \%$ terletak pada rentang $75 \%-100 \%$ dengan kategori valid. 


\section{Aspek pedagogik}

Aspek Pedagogik memiliki 5 komponen penilaian. Skor rata-rata validasi aspek pedagogik adalah 91,67\%. Berdasarkan kriteria validitas modul maka kriteria kelayakan analisis persentase nilai $91,67 \%$ terletak pada rentang $75 \%-100 \%$ dengan kategori valid.

8. Aspek Kegrafisan

Aspek kegrafisan memiliki 7 komponen penilaian. Skor rata-rata validasi aspek kegrafisan adalah 82,14\%. Berdasarkan kriteria validitas modul maka kriteria kelayakan analisis persentase nilai $82,14 \%$ terletak pada rentang $75 \%-100 \%$ dengan kategori valid.

Adapun persentase rata rata dari kedelapan aspek tersebut adalah sebesar 92,77\%. Diagram persentase skor validasi oleh validator disajikan pada Gambar. 2.

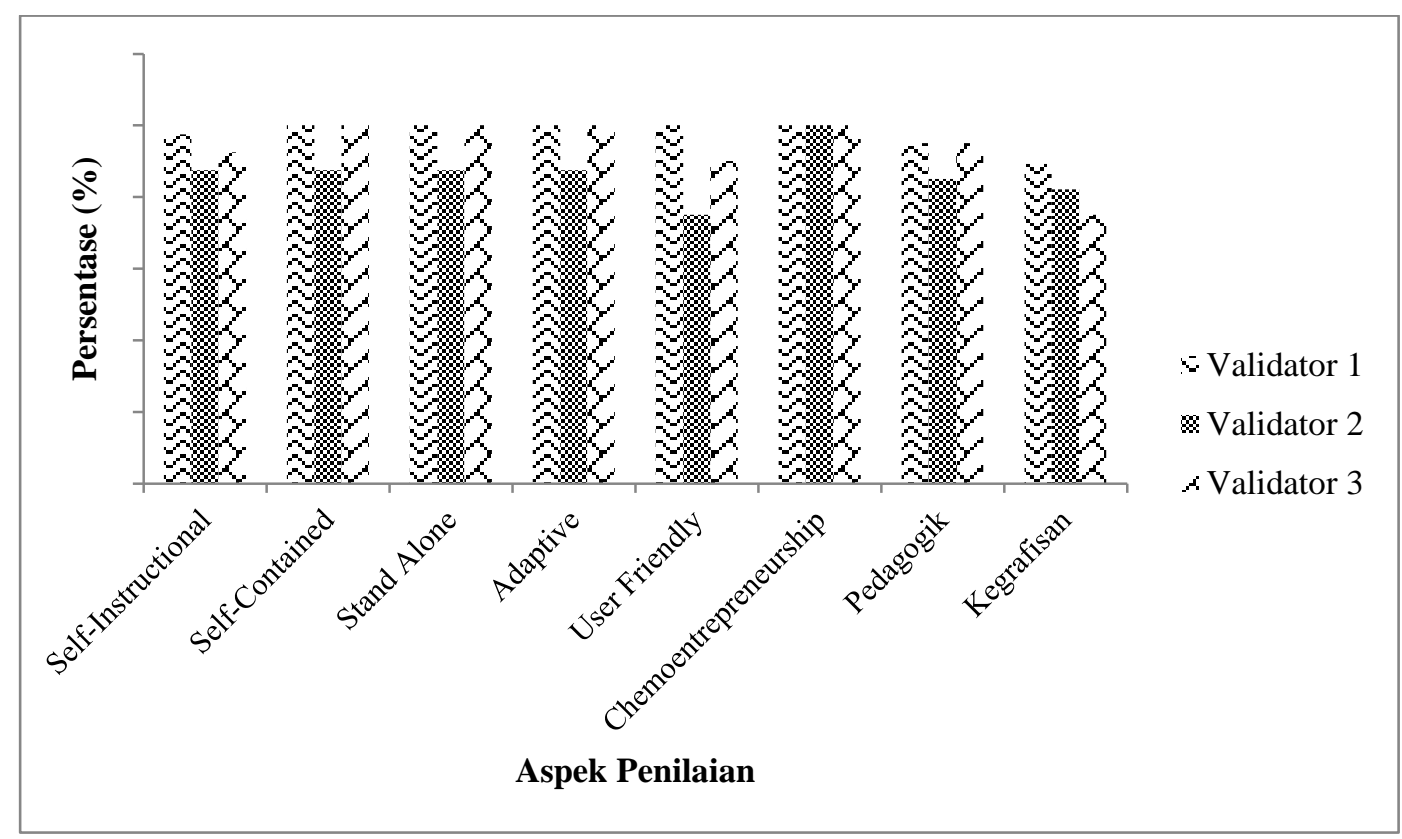

Gambar. 2. Diagram Persentase Skor Validasi

Uji coba bertujuan untuk memperoleh penilaian dan saran dari sisi pengguna yakni guru dan peserta didik modul berorientasi chemoentrepreneurship senyawa turunan alkana. Uji coba kepada guru responden dilakukan kepada tiga orang guru kimia SMA dengan perolehan rata-rata skor total seluruh pernyataan adalah $93,94 \%$ dengan kriteria dapat digunakan tanpa revisi, sedangkan uji coba kepada peserta didik responden dilakukan kepada total dua puluh orang peserta didik yang sudah mempelajari materi senyawa turunan alkana yang merupakan peserta didik yang sudah 
tamat SMA tahun 2018 di Siak kecamatan Koto Gasib. Peserta didik tersebut merupakan siswa/siswi lulusan SMAN 1 Koto Gasib. dengan perolehan persentase ratarata seluruh pernyataan adalah 93,33\% dengan kriteria dapat digunakan tanpa revisi. Berdasarkan respon positir tersebut, maka dapat diperoleh modul berorientasi chemoentrepreneurship senyawa turunan alkana final.

\section{KESIMPULAN}

Modul berorientasi chemoentrepreneurship senyawa turunan alkana untuk kelas XII SMA/MA yang dikembangkan valid berdasarkan aspek self-instructional, self-contained, stand alone, adaptive, user friendly, aspek chemoentrepreneursip, aspek pedagogik dan aspek kegrafisan dengan persentase rata rata sebesar 92,77\%. Skor respon pengguna yaitu guru dan peserta didik berturut turut adalah adalah 93,94\% dan 93,33\% dengan kriteria sangat baik.

\section{DAFTAR PUSTAKA}

Bintari, Ni Luh Gede Riawan P., I Nyoman Sudiana, \& Ida Bagus Putrayasa., 2014, Pembelajaran Bahasa Indonesia Berdasarkan Pendekatan Saintifik (Problem Based Learning) Sesuai Kurikulum 2013 di Kelas VII SMAN Amlapura, ejournal Pasca Sarjana Universitas Pendidikan Ganesha, 3, Universitas Pendidikan Ganesha, Singaraja

Daryanto, 2013, Menyusun Modul Bahan Ajar untuk Persiapan Guru dalam Mengajar, Penerbit Gava Media, Yogyakarta

Herliani,M.phyl,M.S, E., 2016, Modul Guru Pembelajaran Mata Pelajaran Kimia Sekolah Menengah Atas, Direktorat Jendral Guru dan Tenaga Kependidikan, Jakarta

Kementerian Pendidikan dan Kebudayaan, 2016, Silabus Mata Pelajaran Kimia Sekolah Menengah Atas/Madrasah Aliyah (SMA/MA), Kementerian Pendidikan dan Kebudayaan, Jakarta

Rochmad, 2012, Desain Model Pengembangan Perangkat Pembelajaran Matematika, Jurnal Kreano 3 (2), Jurusan Matematika FMIPA UNNES, Semarang

Supartono, N.Wijayanti, \& A.H. Sari., 2009, Kajian Belajar Siswa SMA dengan Metode Student Team Achievement Divisions (STAD) Melalui Pendekatan 
Chemoentrepreneurship (CEP), Jurnal Inovasi Pendidikan Kimia 3 (1), Universitas Negeri Semarang, Semarang

Widoyoko, E P., 2017, Teknik Penyusunan Instrumen Penilaian, Pustaka Belajar, Yogyakarta

Wikhdah, I M., Sri Susilogati Sumarti, \& Sri Wardani., 2015, Pengembangan Modul Larutan Penyangga Berorientasi Chemoentrepreneurship (CEP) untuk Kelas XI SMA/MA, Jurnal Inovasi Pendidikan 9(2), FKIP Universitas Semarang, Semarang

Winarno, A., 2009, Pengembangan Model Pembelajaran Internalisasi Nilai-nilai Kewirausahaan pada Sekolah Menengah Kejuruan di Kota Malang, Jurnal Ekonomi Bisnis, 14 (2) 
MENINGKATKAN PRESTASI BELAJAR KIMIA SISWA KELAS X

MELALUI PENERAPAN METODE TUTOR TEMAN SEBAYA

DI SMA NEGERI 3 BUKIT BATU

Agustini $^{1)}$, Yandriani ${ }^{2)}$

${ }^{1)}$ SMA Negeri 2 Bantan Jl. Budi Luhur Sukamaju Kabupaten Bengkalis Provinsi Riau

${ }^{2)}$ SMA Negeri 1 Bantan Kabupaten Bengkalis Provinsi Riau

Email: agustinihusniwan@gmail.com

\begin{abstract}
Chemistry learning in SMA Negeri 3 Bukit Batu currently less satisfying because there are many problems caused the students less enthusiastic to learn. The means and infrastructure lack of adequate (the package to students limited as well as a tool and material contained in the laboratory chemistry not supportive). Learning less attracted the interest of students so that students easy bored and less active and achievements of learning students low. The research, choose a method tutors peer in the learning process in order to be given the opportunity to students to actively participate. So it can improve understanding of the students against the subject chemical. A method tutors peers done by the held the discussion of the group in order to resolve the issue given teachers and achievements of each groups as well as the provision of the issue of evaluation individually on any of the meeting. With such a lesson chemistry not only listen to explanation from the teacher but concerns discussion as well as a matter of on each of the meeting. The subject used in this study is students of class X SMA Negeri 3 Bukit Batu years lesson 2017/2018 amounting to 20 people. As for the conclusions from this research is the implementation of tutors peers on the material Redoks in class X years lesson 2017/2018, is proven to improve the achievements learn students and indicated by the existence of an increase in the motivation to learn, collaboration between the group and a sense of responsibility to about given.
\end{abstract}

Kata Kunci : tutors peers, achievements chemistry, Redox

\begin{abstract}
Abstrak
Pembelajaran Kimia di SMA Negeri 3 Bukit Batu saat ini kurang memuaskan. Karena masih banyak masalah yang mengakibatkan siswa kurang antusias untuk belajar.
\end{abstract}


Pembelajaran kurang menarik minat siswa sehingga siswa mudah bosan dan kurang aktif; dan prestasi belajar siswa rendah. Peneliti memilih metode tutor teman sebaya dalam proses belajar agar dapat memberikan kesempatan kepada siswa untuk berpartisipasi aktif. Sehingga dapat meningkatkan pemahaman siswa terhadap mata pelajaran Kimia. Metode tutor teman sebaya dilakukan dengan cara mengadakan kegiatan diskusi kelompok guna menyelesaikan persoalan yang diberikan guru dan presentasi dari masing-masing kelompok pada setiap pertemuan. Beberapa siswa pintar dipilih untuk menjadi tutor didsalam kelompoknya masing- masing. Dengan demikian pembelajaran Kimia tidak hanya mendengarkan penjelasan dari guru tetapi menyangkut kegiatan diskusi serta latihan soal di setiap pertemuan. Subjek yang digunakan dalam penelitian ini adalah siswa kelas X SMA Negeri 3 Bukit Batu Tahun Pelajaran 2017/ 2018 yang berjumlah 20 orang. Adapun kesimpulan dari penelitian ini adalah penerapan metode tutor teman sebaya pada materi Redoks di kelas X Tahun Pelajaran 2017/2018, terbukti dapat meningkatkan prestasi belajar siswa, yang diindikasikan dengan adanya peningkatan dalam ulangan harian siswa, kerjasama antar kelompok, dan rasa tanggung jawab terhadap tugas- tugas yang diberikan.

\section{Kata Kunci : tutor teman sebaya, prestasi belajar kimia, Redoks}

\section{PENDAHULUAN}

Belajar adalah suatu bentuk pertumbuhan atau perubahan yang terjadi dalam diri seseorang yang dinyatakan dalam cara-cara bertingkah laku yang baru berkat pengalaman belajar dan latihan. Dalam hal ini peran guru sangat penting untuk memajukan minat dan rasa suka siswa terhadap mata pelajaran yang disampaikan, khususnya mata pelajaran Kimia, sehingga siswa akan selalu ingin belajar dan terus belajar tanpa ada rasa terpaksa. Pada proses pembelajaran dibutuhkan keaktifan dalam pemahaman materi yang diberikan, hal ini juga sangat dipengaruhi oleh penggunaan metode pembelajaran yang tepat. Dengan belajar aktif diharapkan siswa dapat memahami materi yang disampaikan oleh guru sehingga hasil belajar yang didapat juga memuaskan.

Kimia merupakan salah satu mata pelajaran yang penting. Hal ini karena kita tidak akan pernah lepas dengan yang namanya kimia, baik dalam materi pelajaran di sekolah maupun dalam kehidupan sehari- hari. Dibutuhkan pemahaman lebih 
mendalam, keuletan dan ketelitian yang tinggi dalam mempelajari Kimia. Tidak hanya sekedar "mendengar", "mencatat", dan "menghafal" saja. Dalam pelajaran Kimia sering dijumpai soal-soal yang bervariasi sehingga membutuhkan banyak latihan agar siswa terampil dalam mengerjakan soal baik secara individu maupun secara kelompok atau kerjasama tim. Selain itu siswa juga dituntut untuk berfikir lebih kritis dan kreatif agar bisa memahami dengan baik konsep dan pengetahuan baru yang telah diberikan oleh guru. Dengan demikian guru harus pandai dalam menciptakan suasana kelas yang kondusif sehingga dapat membangkitkan semangat siswa dalam mengikuti pelajaran Kimia. Hal ini terkait dengan metode pembelajaran yang diterapkan oleh guru di kelas. Penerapan metode pembelajaran yang tepat oleh guru harus disesuaikan dengan kemampuan, minat dan prestasi yang telah dicapai oleh siswa.

Pembelajaran Kimia di SMA Negeri 3 Bukit Batu saat ini kurang menunjukkan hasil yang memuaskan. Karena masih banyak ditemukan masalah- masalah yang mengakibatkan siswa menjadi kurang antusias. Antara lain: 1). Pembelajaran yang dilakukan kurang menarik minat siswa sehingga siswa mudah bosan dan siswa kurang aktif; dan 2). Prestasi belajar siswa yang rendah.

Berdasarkan ulangan yang dilakukan di kelas X, masih terdapat beberapa siswa yang belum memenuhi standar nilai KKM (Kriteria Ketuntasan Minimal) untuk mata pelajaran Kimia, yaitu 75. Dari hasil ulangan siswa (untuk materi Larutan Elektrolit dan Non Elektrolit) terdapat 13 siswa $(65,00 \%)$ yang mendapatkan nilai di bawah standar nilai KKM dan yang mendapatkan nilai di atas standar nilai KKM sebanyak 7 siswa $(35,00 \%)$ dengan nilai terendah yang diperoleh siswa adalah 32 , sedangkan nilai tertinggi adalah 85. Dari hasil tersebut bisa dilihat prestasi belajar siswa yang tidak merata dan terjadi ketimpangan, sedangkan untuk tugas- tugas rumah yang diberikan oleh guru, sebagian siswa masih mengerjakan di kelas sebelum pelajaran Kimia dimulai. Masih terdapat pula siswa yang mengandalkan kemampuan siswa yang kemampuannya di atas rata- rata dalam mengerjakan ulangan atau latihan soal (mencontek). Ini menunjukkan rendahnya keaktifan dan tanggung jawab siswa dalam mengikuti pelajaran Kimia di SMA Negeri 3 Bukit Batu.

Salah satu metode pembelajaran yang peneliti terapkan dalam pembelajaran Kimia di SMA Negeri 3 Bukit Batu ialah metode belajar tutor teman sebaya. Tutor sebaya adalah seorang siswa pandai yang membantu belajar siswa lainnya dalam tingkat 
kelas yang sama. Alasan peneliti menggunakan metode ini adalah diharapkan siswa menjadi lebih aktif dalam mengikuti proses belajar mengajar karena siswa dapat melakukan diskusi kelompok dengan temannya sendiri serta mengemukakan pendapat mereka tanpa harus ada rasa takut. Dengan metode ini tidak hanya guru yang aktif tetapi juga peran siswa sehingga kondisi kelas menjadi lebih hidup. Selain itu semangat kerjasama kelompok sangat diperlukan dalam menyelesaikan masalah yang diberikan oleh guru.

Penelitian sebelumnya mengenai metode tutor teman sebaya pernah dilakukan oleh Rukamtini (2017) dengan judul Pendekatan Cooperative Learning dengan Tutor Sebaya untuk Meningkatkan Aktivitas dan Prestasi Belajar Kimia Siswa kelas XII MAN 1 Surakarta. Hasil penelitian menunjukkan bahwa penerapan pendekatan cooperative learning dengan metode tutor sebaya dapat meningkatkan aktivitas dan prestasi belajar siswa pada Standar Kompetensi 2, yaitu menerapkan konsep reaksi oksidasi- reduksi dan elektrokimia dalam teknologi dan kehidupan sehari- hari. Melalui pendekatan cooperative learaning dengan tutor sebaya dapat menumbuhkan rasa senang terhadap proses dan materi pembelajaran sehingga meningkatkan pemahaman terhadap materi pembelajaran khususnya bagi siswa kelas XII.IA-2 MAN 1 Surakarta pada semester Gasal Tahun Pelajaran 2013/2014 yang tinggal di asrama.

Penelitian lain dilakukan oleh Nurpaidah (2016) dengan judul Peningkatan Kualitas Hasil Belajar Kimia (Oksidasi Reduksi) pada Siswa Kelas X SMA Negeri 3 Watampone melalui Pembelajaran Remedial dengan Tutor Sebaya. Penelitian ini merupakan penelitian tindakan kelas. Penggunaan model pembelajaran remidial dengan tutor sebaya mampu meningkatkan hasil belajar siswa karena dalam model pembelajaran remidial dengan tutor sebaya siswa dapat memahami tujuan pentingnya pelajaran, informasi, dan keterampilan yang diperoleh siswa terstruktur dengan baik, tersedianya waktu ekstra untuk pelatihan terbimbing adanya pemberian umpan balik terhadap tugas, pemberian latihan mandiri, dan penerapan konsep yang dipelajari pada kehidupan seharihari. Hasil analisis data dilakukan dengan observasi dan tes hasil belajar. Hasil penelitian menunjukkan bahwa dalam pembelajaran dengan menerapkan metode tutor sebaya siswa Kelas X SMA Negeri 3 Watampone mengalami peningkatan dan mencapai kualitas hasil belajar. 
Penelitian selanjutnya dilakukan oleh Wiqoyati (2013). Peningkatan Hasil Belajar Kimia Materi Senyawa Hidrokarbon Siswa SMAN 1 Kaliwungu dengan Metode "TUBA ASYIK". Penelitian dilakukan dengan pembelajaran yang menyenangkan antara lain melalui tutor sebaya dan diskusi informasi. Disimpulkan bahwa metode TUBA Asyik merupakan suatu metode pembelajaran yang dapat meningkatkan hasil belajar siswa terhadap Senyawa Hidrokarbon serta dapat meningkatkan motivasi belajar siswa.

Kuswaya Wihardit (dalam Dimyati, 2006) menuliskan bahwa Pengertian tutor sebaya adalah seorang siswa pandai yang membantu belajar siswa lainnya dalam tingkat kelas yang sama. Sedangkan menurut Arikunto (2008) menyatakan bahwa: "tutor sebaya adalah seseorang atau beberapa orang siswa yang ditunjuk oleh guru sebagai pembantu guru dalam melakukan bimbingan terhadap kawan sekelas". Sedangkan Hisyam Zaini (dalam Dimyati, 2006) menyatakan bahwa: Metode belajar yang paling baik adalah dengan mengajarkan kepada orang lain. Oleh karena itu, pemilihan metode pembelajaran tutor sebaya sebagai strategi pembelajaran akan sangat membantu siswa di dalam mengajarkan materi kepada teman-temannya.

Arikunto (2008) mengemukakan bahwa dalam memilih tutor perlu diperhatikan hal-hal sebagai berikut: a). tutor dapat diterima (disetujui) oleh mayoritas siswa sehingga siswa tidak mempunyai rasa takut atau enggan untuk bertanya kepadanya; b). tutor dapat menerangkan bahan yang akan diajarkan yang dibutuhkan oleh siswa yang lain dalam kegiatan belajar mengajar; c). tutor tidak tinggi hati, kejam atau keras hati terhadap sesama kawan; dan d). tutor mempunyai daya kreativitas yang cukup untuk memberikan bimbingan, yaitu dapat menerangkan pelajaran kepada kawannya.

Menurut Djamarah (2006) menerangkan bahwa untuk menentukan siapa yang akan dijadikan tutor diperlukan pertimbangan-pertimbangan sendiri, diantaranya adalah: a). memiliki kepandaian lebih unggul dari pada yang lain; b). memiliki kecakapan dalam menerima pelajaran yang disampaikan oleh guru; c). mempunyai kesadaran untuk membantu teman lain; d). dapat menerima dan disenangi siswa yang mendapat program tutor sebaya, sehingga siswa tidak mempunyai rasa takut atau enggan untuk bertanya kepada yang pandai dan rajin; e). tidak tinggi hati, kejam, atau keras hati terhadap sesama kawan; dan f). mempunyai daya kreativitas yang cukup untuk memberikan bimbingan atau yaitu dapat menerangkan kepada kawannya. 
Adanya kegiatan diskusi kelompok ini diharapkan dapat meningkatkan keaktifan siswa dalam mengikuti kegiatan belajar mengajar yang diselenggarakan oleh sekolah. Siswa akan lebih termotivasi dalam mengemukakan pendapat, mengajukan pertanyaan dan menjawab pertanyaan pada saat dilakukan diskusi kelompok. Kegiatan diskusi kelompok ini diharapkan dapat menumbuhkan keberanian dalam diri siswa pada saat menjelaskan hasil diskusi kelompok di kelas.

Pembelajaran yang dilakukan dengan metode tutor teman sebaya dapat memberikan kesempatan kepada siswa untuk berpartisipasi aktif dalam diskusi kelompok. Sehingga dapat meningkatkan prestasi belajar serta pemahaman siswa terhadap mata pelajaran Kimia yang dilakukan dengan cara mengadakan kegiatan diskusi kelompok guna menyelesaikan persoalan yang diberikan guru dan presentasi dari masing- masing kelompok serta pemberian soal-soal evaluasi sacara individu pada setiap pertemuan. Dengan demikian pembelajaran Kimia tidak hanya mendengarkan penjelasan dari guru tetapi menyangkut kegiatan diskusi kelompok serta latihan soal di setiap pertemuan. Melalui penerapan metode tutor teman sebaya diharapkan dapat meningkatkan prestasi belajar Kimia siswa.

Adapun tujuan penelitian tindakan ini adalah untuk mengetahui bagaimana peningkatan prestasi belajar Kimia (pokok bahasan Redoks) siswa kelas X melalui penerapan metode tutor teman sebaya di SMA Negeri 3 Bukit Batu.

\section{METODE PENELITIAN}

Penelitian ini merupakan Penelitian Tindakan Kelas (PTK). Penelitian Tindakan Kelas merupakan suatu bentuk penelitian yang dilakukan oleh guru di kelas atau di sekolah tempat ia mengajar. Hal ini dilakukan sebagai upaya untuk memperbaiki keadaan yang kurang memuaskan dan untuk meningkatkan mutu pembelajaran di kelas.

Subjek yang digunakan dalam penelitian ini adalah siswa kelas X SMA Negeri 3 Bukit Batu Tahun Pelajaran 2017/ 2018 yang berjumlah 20 orang. Penelitian dilaksanakan pada bulan Januari sampai bulan Mei 2018 pada Semester Genap Tahun Pelajaran 2017/ 2018 di SMA Negeri 3 Bukit Batu Jalan Budi Utomo Desa Bukit Kerikil Kecamatan Bukit Batu Kabupaten Bengkalis.

Prosedur penelitian merupakan tahapan- tahapan yang ditempuh dalam 
penelitian dari awal sampai akhir secara urut. Prosedur penelitian ini terdiri dari beberapa kegiatan, yaitu :

1. Tahap Pengenalan Masalah. Kegiatan yang dilakukan pada tahap ini adalah:

a. Mengidentifikasi masalah

b. Menganalisis masalah secara mendalam dengan mengacu pada teori-teori yang relevan

2. Tahap Persiapan dan Penyusunan rencana tindakan. Pada tahap ini peneliti melakukan persiapan yang meliputi :

a. Menyusun bentuk tindakan yang sesuai dengan siklus pertama

b. Menyusun alat observasi

c. Penyusunan jadwal penelitian

d. Penyusunan rencana pembelajaran

e. Penyusunan soal evaluasi

Rencana tindakan disusun dalam dua siklus, yaitu : siklus I dan siklus II. Setiap siklus terdiri dari empat tahap, yaitu tahap perencanaan tindakan, pelaksanaan tindakan, observasi dan interpretasi serta tahap analisis dan refleksi.

3. Tahap Implementasi Tindakan, merupakan implementasi atau penerapan isi rancangan mengenai tindakan di kelas. Pada tahap ini peneliti menentukan hipotesis tindakan yaitu alternatif tindakan yang dipandang paling tepat atau dipercaya oleh peneliti dan akan mampu memecahkan masalah yang sedang dihadapi.

4. Tahap Observasi atau Pengamatan, yaitu tahap pelaksanaan pengamatan oleh peneliti. Kegiatan observasi atau pengamatan dalam penelitian tindakan kelas dilakukan untuk mengetahui dan memperoleh gambaran lengkap secara obyektif tentang perkembangan proses pembelajaran dan pengaruh dari tindakan yang dipilih terhadap kondisi kelas dalam bentuk data.

5. Tahap Penyusunan Laporan. Pada tahap ini peneliti menuyusun laporan dari semua kegiatan yang telah dilakukan selama penelitian.

Data yang diperoleh kemudian dianalisis dengan menggunakan analisis statistik deskriptif. Kemudian diklasifikasikan ke dalam dua kelompok yaitu data kualitatif dan kuantitatif. Analisis ini bertujuan untuk memperlihatkan tingkat penguasaan dan ketuntasan/ keberhasilan belajar siswa. Seorang siswa dikatakan tuntas secara individu, apabila siswa tersebut memperoleh daya serap minimal $75 \%$, sedangkan ketuntasan 
klasikal sebesar (85\%). Analisis data dengan nilai perkembangan siswa dilakukan untuk mengetahui bagaimana perkembangan siswa setelah penerapan pembelajaran dengan metode tutor teman sebaya dalam pembelajaran Kimia. Nilai perkembangan siswa dilihat dari skor dasar, UH I dan UH II. Persentase ketuntasan ini dihitung dengan menggunakan rumus sebagai berikut:

1. Ketuntasan Belajar Siswa Individu (KBSI), menggunakan rumus:

$$
\text { KBSI }=\frac{\text { Skor Yang Diperoleh Siswa }}{\text { Skor Maksimal }} \times 100 \%
$$

2. Ketuntasan Belajar Siswa Klasikal (KBSK), menggunakan rumus:

$$
\text { KBSK }=\frac{\text { Jumlah Siswa Yang Tuntas }}{\text { Jumlah Siswa Keseluruhan }} \times 100 \%
$$

3. Daya Serap Siswa (DSS), menggunakan rumus:

$$
\text { DSS }=\frac{\sum \text { Skor Perolehan }}{} \times \frac{100 \%}{\sum \text { Skor Maksimal }}
$$

(Depdiknas, 2004)

\section{HASIL DAN PEMBAHASAN}

Berdasarkan hasil kegiatan identifikasi dan analisis masalah bekerjasama dengan teman sejawat dan supervisor, kemudian diadakan rancangan perbaikan pembelajaran sesuai dengan tujuan perbaikan yang telah ditetapkan. Dengan demikian penulis melaksanakan perbaikan pembelajaran Kimia pada materi Reaksi Oksidasi dan Reduksi (Redoks).

Adapun langkah- langkah penelitian yang akan dilakukan pada siklus I adalah:

1. Guru menyampaikan ruang lingkup materi, selanjutnya guru menyampai tujuan pembelajaran yang akan dicapai.

2. Guru menyampaikan metode yang digunakan dan menyampaikan rambu- rambu penilaian.

3. Guru menjabarkan materi Redoks melalui metode ceramah, lalu memberi tugas kepada siswa untuk membaca handout sehubungan materi guna memperdalam pengetahuannya. 
4. Guru meminta beberapa orang untuk menjawab beberapa pertanyan yang diberikan oleh guru, guru juga mengamati kemampuan siswa yang cepat tanggap/ faham untuk dijadikan tutor bagi teman- temannya.

5. Siswa yang dianggap cepat menguasai Materi Redoks, lalu ditunjuk sebagai tutor yang bertugas membantu teman- temannya menjelaskan mengenai materi dan membantu teman- temannya mengerjakan tugas. (Masing- masing kelompok ditunjuk 1 orang siswa sebagai tutor).

6. Perintahkan beberapa siswa yang paling baik dalam beberapa kategori penilaian untuk menjelaskan materi dan diberi penghargaan atas usaha mereka.

Berdasarkan kenyataan yang ditemui dalam kegiatan monitoring dan hasil tes siswa pada siklus I, peneliti dapat merefleksikan hal-hal sebagai berikut :

1. Siswa terlihat antusias mengikuti proses pembelajaran, hanya saja sebagian besar siswa terlihat kebingungan dengan materi dan metode yang tergolong baru bagi siswa.

2. Masih ditemui sebagian siswa yang tidak dapat menyelesakan tugas tepat pada waktu yang ditentukan

3. Suasana kelas yang terlihat riuh akibat siswa yang ingin mencari informasi tentang materi Redoks

4. Siswa selaku tutor tidak mempunyai banyak waktu untuk menyelesaikan tugasnya, karena banyak teman- temannya yang bertanya

5. Masih dijumpai nilai siswa yang belum tuntas, maka perlu dilakukan perbaikan pada siklus II.

Adapun pelaksanaan tindakan yang dilakukan pada siklus II ini dilaksanakan dengan melaksanakan langkah- langkah perbaikan sebagai berikut:

1. Memberikan motivasi dan kepercayaan kepada siswa untuk memaksimalkan hasil.

2. Membimbing siswa mengerjakan tugasnya sesuai prosedur.

3. Siswa dibagi mejadi 5 kelompok.

4. Siswa yang dianggap teliti, cermat dan cepat fahamnya ditunjuk sebagai tutor oleh guru, (satu kelompok ditunjuk 2 orang tutor).

5. Beberapa siswa yang paling baik dalam beberapa kategori penilaian untuk mempresentasekan hasil karya mereka dengan menjelaskan prosedur kerjanya. 
Adapun hasil pengamatan pelaksanaan tindakan pada siklus II adalah sebagai berikut :

1. Motivasi siswa untuk belajar semakin meningkat, hal ini terjadi karena siswa menemukan hal baru dalam proses belajar.

2. Kegiatan pembelajaran berjalan lancar, hal ini terlihat dari ketepatan siswa menyelesaikan tugasnya.

3. Siswa antusias mengikuti kegiatan belajar mengajar.

4. Siswa bekerja dengan kepercayaan diri yang tinggi.

5. Siswa selaku tutor juga dapat menyelesaikan pekerjaannya dengan baik

6. Hasil belajar meningkat.

Berdasarkan kenyataan yang ditemui dalam kegiatan monitoring dan hasil tes siswa pada siklus II, peneliti dapat merefleksikan hal- hal sebagai berikut :

1. Siswa mulai mengerti dan tidak asing tentang materi Redoks yang diberikan oleh guru

2. Siswa sudah terbiasa dengan metode tutor teman sebaya.

3. Kegagalan belajar sebagian siswa sudah teratasi, hal ini dapat dilihat pada hasil belajar siswa. Hasil belajar siswa meningkat, baik kualitas maupun kuantitas.

4. Aktivitas siswa siswa dalam mengerjakan tugas sangat tinggi

5. Karena hasil belajar siswa meningkat, dan tingkat kegagalan siswa sudah berkurang, maka tidak dilakukan perbaikan pada siklus berikutnya.

\section{HASIL PENELITIAN}

Data hasil penelitian ketuntasan individu dan klasikal siswa Kelas X SMA Negeri 3 Bukit Batu Tahun Pelajaran 2017/2018 dengan menerapkan metode tutor teman sebaya.

Tabel1. Ketuntansan Hasil Belajar Siswa

\begin{tabular}{|c|c|c|c|c|}
\hline \multirow{4}{*}{ No } & \multirow{4}{*}{ Kegiatan } & \multicolumn{3}{|c|}{ Ketuntasan Belajar } \\
\hline & & \multicolumn{2}{|c|}{ Individu } & \multirow[b]{2}{*}{ Klasikal } \\
\hline & & Tuntas & $\begin{array}{c}\text { Tidak } \\
\text { Tuntas }\end{array}$ & \\
\hline & & $\mathbf{N}(\%)$ & $\mathrm{N}(\%)$ & $\mathrm{N}(\%)$ \\
\hline 1 & Ulangan I (Siklus I) & $12(60 \%)$ & $8(40 \%)$ & $60 \%$ ( Tuntas) \\
\hline 2 & Ulangan II (Siklus II) & $18(90 \%)$ & $2(10 \%)$ & $90 \%$ (Tuntas) \\
\hline
\end{tabular}


Data pada Tabel 1 di atas menggambarkan hasil belajar setelah dilakukan perbaikan terjadi peningkatan. Dimana pada siklus I ketuntasan individu siswa terdapat sebanyak $12(60 \%)$ dan siswa yang tidak tuntas $8(40 \%)$. Setelah dilakukan perbaikan tindakan pada siklus II, ketuntasan individu siswa meningkat menjadi 18 (90\%) siswa yang tuntas, dan sebanyak $2(10 \%)$ siswa yang tidak tuntas, jadi mengalami peningkatan sebesar $(30 \%)$.

Begitu juga perubahan yang terjadi pada ketuntasan klasikal. Pada siklus I hanya (60\%) siswa yang tuntas, pada siklus II ketuntasan klasikal mengalami peningkatan menjadi (90\%), meningkat sebesar (30\%). Peningkatan tidak hanya terjadi pada hasil belajar siswa, namun dengan menerapkan metode tutor sebaya siswa juga bisa mempertanggungjawabkan terhadap pekerjaannya dengan menyerahkan tugas sesuai dengan jadwal yang ditentukan.

Selanjutnya data hasil penelitian sehubungan daya serap siswa kelas X SMA Negeri 3 Bukit Batu Tahun Pelajaran 2017/2018, dengan menerapkan metode tutor teman sebaya, dapat dilihat pada Tabel berikut.

Tabel 2. Daya Serap Siswa

\begin{tabular}{cccc}
\hline \multirow{2}{*}{ Kategori } & Siklus I & Siklus II \\
\cline { 3 - 4 } & & $\mathbf{N}(\boldsymbol{\%})$ & $\mathbf{N}(\boldsymbol{\%})$ \\
\hline 1 & $90-100$ (Amat Baik) & $2(10 \%)$ & $6(30 \%)$ \\
\hline 2 & $80-89$ (Baik) & $6(30 \%)$ & $8(40 \%)$ \\
\hline 3 & $70-79$ (Cukup) & $7(35 \%)$ & $4(20 \%)$ \\
\hline 4 & $60-69$ (Kurang) & $3(15 \%)$ & $1(5 \%)$ \\
\hline 5 & $<60$ (Amat Kurang) & $2(10 \%)$ & $80 \%$ \\
\hline \multicolumn{2}{l}{ Rata-Rata (Daya Serap) } & $70 \%$ & $8(5 \%)$ \\
\hline
\end{tabular}

Berdasarkan data pada Tabel 2 tentang daya serap siswa pada mata pelajaran Kimia materi Redoks dapat dijelaskan, bahwa pada siklus I siswa yang memperoleh rentang nilai 90-100 2(10\%), tetapi setelah dilakukan perbaikan pada siklus II mengalami peningkatan yang signifikan, yaitu sebanyak 6(30\%), terjadi peningkatan sekitar (20\%). Sedangkan siswa yang memperoleh rentang nilai 8 0- 896 (30\%), dan 
setelah dilakukan perbaikan pada siklus II maka daya serap siswa yaitu sebanyak 8 (40 \%) siswa yang memperoleh rentang nilai 70- 79 pada siklus I $7(35 \%)$ pada siklus 2 menjadi 4 (20), sedangkan rentang nilai 60 - 69 pada siklus I terdapat sebanyak 3 (7\%) setelah dilakukan perbaikan pada siklus II sudah berkurang 1(5\%), dan siswa yang memperoleh nilai < 60 pada siklus I $2(10 \%)$, pada siklus II hanya 1 orang siswa yang memperoleh nilai <60 1(5\%). Sedangkan daya serap siswa pada siklus I hanya sebesar 70\%. Setelah dilakukan perbaikan pada siklus II, daya serap siswa mengalami peningkatan menjadi (80\%), mengalami peningkatan sebesar (10\%).

\section{PEMBAHASAN}

Berdasarkan hasil analisis data setelah dilakukan tindakan, pemantauan, evaluasi dan refleksi perbaikan terhadap pembelajaran Kimia pada materi Redoks siswa kelas X SMA Negeri 3 Bukit Batu Tahun Pelajaran 2017/2018, dimana hasil pembelajaran siswa, prestasi belajar siswa menunjukkan perubahan sangat positif. Baik dari segi ketuntasan individu, ketuntasan klasikal, dan daya serap siswa.

Pada siklus I ketuntasan belajar siswa, baik ketuntasan individu maupun klasikal mengalami peningkatan cukup signifikan. Dari 20 siswa yang mengikuti evaluasi terdapat $12(60 \%)$ siswa yang tuntas dan terdapat $9(45 \%)$ siswa yang tidak tuntas. Selanjutnya setelah dilakukan perbaikan pada siklus II terdapat sebanyak $18(90 \%)$ siswa yang tuntas dan 2(10\%) siswa yang tidak tuntas, mengalami peningkatan ketuntasan sebesar (30\%).

Untuk ketuntasan klasikal pada siklus I 60\%, setelah dilakukan perbaikan pada siklus II, ketuntasan klasikal siswa meningkat lagi menjadi 90\%, meningkat sebesar $(30 \%)$. Sementara daya serap siswa pada siklus I hanya sebesar (73\%), setelah dilakukan perbaikan pada siklus II mengalami peningkatan menjadi (78\%), meningkat sebesar $(5 \%)$.

Meningkatnya hasil belajar Mata Pelajaran Kimia pada materi Redoks dapat dikatakan karena pemilihan metode yang tepat, dimana siswa dapat mendapatkan informasi mengenai materi Redoks, secara menyeluruh walaupun bagi siswa materinya sangat awam dan belum pernah dipelajari sama sekali. Hal ini disebabkan informasi tentang materi tidak hanya dari satu sumber (guru) tetapi bisa didapat dari beberapa sumber (tutor teman sebaya), Siswa tidak lagi hanya mendengar materi yang disampaikan guru, atau memperhatikan apa yang didemonstrasikan oleh guru saja tetapi 
lebih dari itu siswa secara langsung terlibat dalam persiapan pembelajaran, menentukan dan menerapkan metode pembelajaran.

Dengan menggunakan metode tutor teman sebaya sangat membantu siswa yang lambat pemahamannya, atau siswa yang malu atau riskan bertanya dengan guru. Sehingga seluruh siswa dapat menerima ilmu yang disampaikan dengan merata. Sementara bagi siswa yang ditunjuk guru sebagai tutor, merasa bangga karena mendapat kepercayaan yang luar biasa dari guru, selain itu dengan membantu temannya berarti mereka memiliki kesempatan untuk terus mengulang- ulang kemampuan/ skillnya sehingga siswa tersebut bisa lebih mengasah lagi kemampuan atau skillnya. Selanjutnya dengan menggunakan metode tutor teman sebaya juga diharapkan siswa dapat menemukan pemantapan materi yang diberikan.

Selain beberapa faktor diatas pembelajaran Redoks ini terlaksana dengan baik dalam suasana yang sangat kondusif, sehingga aktifitas belajar maksimal dan hasil belajar meningkat. Ini dikarenakan adanya media benda asli yang digunakan oleh guru, dimana dengan menggunakan metode tutor teman sebaya ini siswa dapat melihat secara langsung dan dapat dijadikan acuan dalam melaksanakan materi Redoks sesuai tugas yang diberikan oleh guru.

Dengan keterlibatan secara langsung siswa dalam proses pembelajaran tersebut, akan memudahkan siswa memahami materi yang disajikan. Sehingga siswa dapat mengerjakan tugas- tugas yang diberikan khususnya tugas- tugas yang diberikan oleh guru bidang studi Kimia dengan baik, dan diharapkan akan memudahkan siswa mencerna dan mengimplementasikan materi ajar dalam menyelesaikan soal- soal yang diberikan guru dan dalam realita kehidupan sehari- hari.

\section{KESIMPULAN}

Adapun kesimpulan dari penelitian ini adalah penerapan metode tutor teman sebaya pada materi Redoks di kelas X SMA Negeri 3 Bukit Batu Tahun Pelajaran 2016/ 2017, terbukti dapat meningkatkan prestasi belajar siswa, yang diindikasikan dengan adanya peningkatan dalam hasil ulangan belajar siswa, kerjasama antar kelompok, dan rasa tanggung jawab terhadap tugas-tugas yang diberikan. Penerapan metode tutor teman sebaya pada materi Redoks di kelas X SMA Negeri 3 Bukit Batu Semester II 
Tahun Pelajaran 2017/2018, dapat meningkatkan hasil belajar siswa terbukti nilai hasil Ulangan Harian pada siklus II terdapat peningkatan yang signifikan.

\section{DAFTAR PUSTAKA}

Arikunto, Suharsimi Suhardjono dan Supardi, 2008, Penelitian Tindakan Kelas. Bumi Aksara, Jakarta

Depdiknas, 2004, Rambu- Rambu Penetapan Standar Ketuntasan Belajar Minimum dan Analisis Hasil Pencapaian Standar Keuntasan Belajar. Depdiknas, Jakarta

Dimyati, 2006, Belajar dan Pembelajaran, Rineka Cipta, Jakarta

Djamarah, Syaiful Bahri dan Aswin, 2006, Strategi Belajar Mengajar, Rineka Cipta, Jakarta

Nurpaidah, Siti., 2016,. Peningkatan Kualitas Hasil Belajar Kimia (Oksidasi Reduksi) pada Siswa Kelas X SMA Negeri 3 Watampone Melalui Pembelajaran Remedial dengan Tutor Sebaya, Jurnal Chemica, 17 (1).

Rukamtini, 2017, Pendekatan Cooperative Learning dengan Tutor Sebaya untuk Meningkatkan Aktivitas dan Prestasi Belajar Kimia Siswa MAN 1 Surakarta. Jurnal Pendidikan Madrasah, 2 (2).

Wiqoyati, Siti Nur., 2013, Peningkatan Hasil Belajar Kimia Materi Senyawa Hidrokarbon Siswa SMAN 1 Kaliwungu dengan Metode "TUBA ASYIK", Jurnal Inovasi Pendidikan Kimia, 7 (2). 


\title{
PENGEMBANGAN MODUL KIMIA BERBASIS POE (PREDICT, OBSERVE, AND EXPLAIN) PADA MATERI SIFAT KOLIGATIF LARUTAN SEBAGAI SUMBER BELAJAR PESERTA DIDIK KELAS XII SMA/MA

\author{
Roza Novia Putri*, Erviyenni*, Betty Holiwarni *
} \\ Email: *rozaputrinovia@gmail.com,*erviyenni@gmail.com,*holi_warni@yahoo.com Phone: 082391101407 \\ Program Studi Pendidikan Kimia \\ Fakultas Keguruan Dan Ilmu Pendidikan \\ Universitas Riau
}

\begin{abstract}
The development of POE-based chemical modules on the colligative properties of the solution aims to obtain a valid chemical module based on the content feasibility, language, graphics, and presentation aspects. The research method of developing chemical module using 4-D model consists of four stages: Define (define) stage, Design stage, Development stage and Desseminate stage. In this research only carried out until the development stage. Data collection techniques are using validation sheets given to two validators aim to assess the chemical modules that have been developed. The result of the research shows the acquisition of feasibility aspect of content $97.01 \% ; 100 \%$ language feasibility aspect; aspect of $97.91 \%$ feasibility of aquality; and the feasibility aspect of $98.21 \%$ presentation. The average of validation score of all POE based chemical modules on the colligative properties of the solution is $96.7975 \%$ with very good category (very valid). Valid chemical modules are then tested to respondents. The respondents were limited to 4 chemistry teachers from SMA N 5 Pekanbaru and SMA N 8 Pekanbaru and 20 students from SMA N 5 Pekanbaru and SMA N 8 Pekanbaru. Analysis of user response data based on teachers 'sheets and learners' scored $93.667 \%$ and $89.53 \%$. The overall avarege validation and limited validity testing scores stated that chemical modules based on POE can be used in the learning process.
\end{abstract}

Keywords: Module, POE, Colligative Properties of Solution 


\begin{abstract}
Abstrak
Pengembangan modul kimia berbasis POE pada materi sifat koligatif larutan bertujuan untuk memperoleh modul kimia yang valid berdasarkan aspek kelayakan isi, bahasa, kegrafikan, dan penyajian. Metode penelitian pengembangan modul kimia menggunakan model 4-D, terdiri atas empat tahapan yaitu tahap Define (pendefenisian), tahap Design (perancangan), tahap Development (pengembangan) dan tahap Desseminate (penyebaran). Pada penelitian ini hanya dilakukan hingga tahap pengembangan. Teknik pengumpulan data menggunakan lembar validasi yang diberikan kepada dua orang validator bertujuan untuk menilai modul kimia yang telah dikembangkan. Hasil penelitian menunjukkan perolehan skor aspek kelayakan isi 97,01\% ; aspek kelayakan bahasa $100 \%$; aspek kelayakan kegrafikan 97,91\% ; dan aspek kelayakan penyajian 98,21 \%. Jadi skor rata-rata validasi keseluruhan modul kimia berbasis POE pada materi sifat koligatif larutan yaitu 96,7975 \% dengan kategori sangat baik (sangat valid). Modul kimia yang telah valid kemudian diuji cobakan kepada responden. Responden uji coba terbatas terdiri atas 4 orang guru kimia dari SMA N 5 Pekanbaru dan SMA N 8 Pekanbaru serta 20 orang peserta didik dari SMA N 5 Pekanbaru dan SMA N 8 Pekanbaru. Analisis data tanggapan pengguna berdasarkan lembar guru dan peserta didik memperoleh skor 93,667\%. dan 89,53\%. Skor rata-rata validasi keseluruhan dan uji coba terbatas menyatakan Modul Kimia berbasis POE dapat digunakan dalam proses pembelajaran.
\end{abstract}

Kata Kunci : Modul, POE, Sifat Koligatif Larutan

\title{
PENDAHULUAN
}

Pembelajaran di SMA cenderung belum menekankan pada pemberian pengalaman belajar melalui penggunaan dan pengembangan keterampilan proses. Sebagai akibatnya peserta didik kesulitan mengaitkan antara materi pembelajaran kimia dengan objek atau fenomena-fenomena yang bermanfaat di sekitar kehidupan manusia. Padahal, arti sebenarnya dari belajar kimia adalah upaya untuk mengetahui berbagai fenomena atau gejala alam agar mendapatkan sesuatu yang bermanfaat bagi kehidupan manusia. Paradigma Pendidikan Nasional Abad 21 yang telah dikeluarkan Badan Standar Nasional Pendidikan (BNSP), pembelajaran kimia dituntut untuk tidak lagi berpusat pada guru (teacher-centered), melainkan berpusat pada peserta didik (student- 
centered). Pembelajaran kimia harus menekankan pada keterkaitan antara materi yang dipelajari (konten) dan masalah-masalah yang ada dalam kehidupan nyata (konteks) peserta didik (BNSP, 2010).

Berdasarkan hasil pengamatan peneliti di SMA Negeri 10 Pekanbaru, belum ada modul kimia berbasis model pembelajaran yang sesuai dengan kurikulum 2013 yang dikembangkan oleh guru. Keadaan ini menjadi semakin sulit saat buku teks yang diharapkan mampu menjelaskan konsep penting ada dalam jumlah yang terbatas artinya tidak semua peserta didik dapat memilikiya maka banyak diantara peserta didik yang tidak memahami materi.

Mengatasi masalah di atas maka perlu diberikan solusi berkaitan dengan sarana pendidikan dalam hal sumber belajar peserta didik. Prastowo (2014) menyebutkan bahwa modul merupakan salah satu sarana sebagai sumber belajar tipe Learning Resources by Design yaitu sumber belajar yang sengaja direncanakan dan dibuat untuk mencapai tujuan pembelajaran tertentu.

Model POE (Predict, Observe, Explain) merupakan model pembelajaran yang dikembangkan dalam pendidikan sains. Model ini dilandasi oleh teori konstruktivisme yakni dengan menggali pengetahuan yang telah diperoleh atau dimiliki peserta didik sebelumnya dan kemudian menginterpretasikannya serta mengkaitkan dengan kehidupan sehari-hari melalui tiga tahapan utama yaitu prediksi (predict), observasi (observe), dan menjelaskan hasil pengamatan (explain) (Warsono, 2012). Indrawati (2009) juga menambahkan model POE dapat menyelidiki gagasan peserta didik dan cara mereka dalam menerapkan pengetahuan pada keadaan yang sebenarnya maka peserta didik dapat membangun pengetahuan baru berdasarkan pengetahuan yang telah dimilikinya yang saling memiliki keterkaitan.

Pernyataan Warsono sesuai dengan pendapat Kearney (2004) yaitu bahwa POE memuat tiga tahapan yang meliputi prediksi, observasi, dan eksplanasi. Pada tahap prediksi, peserta didik membuat prediksi dan memperkirakan hasil pengamatan yang akan dilakukan pada tahap selanjutnya. Kemudian, peserta didik mengamati fenomena yang terjadi atau melihat eksperimen pada fase observasi. Pada tahapan terakhir, peserta didik membandingkan observasi mereka dengan prediksi dan kemudian menjelaskan observasi dengan pengetaahuan mereka sendiri. 
Widyaningrum (2013) mengemukakan bahwa dalam POE dapat meningkatkan pemahaman konsep sains peserta didik. Hal ini juga didukung oleh hasil penelitian Rahayu (2013) yang menyatakan bahwa model pembelajaran POE mampu meningkatkan ketuntasan hasil belajar peserta didik secara individual. Oleh karena itu, penggunaan berbagai sarana prasarana dan sumber belajar yang memadai sangat penting dan menunjang pembelajaran berbasis model POE (Predict, Observe, Explain).

Berdasarkan pernyataan Tanti, Aria dan Dodi (2016) modul berbasis POE menuntut peserta didik untuk berperan aktif dan memberikan pengertian bahwa aktivitas belajar berawal dari sudut pandang peserta didik bukan dari guru atau ahli. Modul berbasis POE dapat digunakan untuk merangsang peserta didik berfikir secara sains dengan mengaitkan antara konten pembelajaran dan konteks kehidupan nyata serta sesuai dengan tuntutan kurikulum 2013 karena modul berbasis POE disusun berdasarkan tahapan pembelajaran yang terdiri atas tahap prediksi, observasi, dan menjelaskan.

Sifat koligatif larutan merupakan salah satu materi dalam pembelajaran kimia yang memiliki hubungan erat dengan kehidupan sehari-hari. Adanya modul kimia yang berbasis POE pada materi sifat koligatif larutan dapat membantu peserta didik untuk melihat manfaat mempelajari materi sifat koligatif larutan dan keterpakaiannya dalam kehidupan sehari-hari sehingga pembelajaran kontekstual yang diinginkan dapat tercapai.

Berdasarkan latar belakang tersebut, maka peneliti melakukan penelitian pengembangan yang berjudul: Pengembangan Modul Kimia Berbasis Poe (Predict, Observe, And Explain) Pada Materi Sifat Koligatif Larutan Sebagai Sumber Belajar Peserta Didik Kelas XII SMA/MA.

\section{METODE PENELITIAN}

Jenis penelitian adalah penelitian pengembangan yang mengacu pada pendekatan penelitan Research and Development (R\&D). Proses pengembangan menggunakan model 4-D (Define, Design, Development, Desseminate) sebagai sebuah model desain yang dipandang sangat cocok untuk pengembangan modul kimia berbasis POE. Penelitian pengembangan model Four-D khususnya pengembangan media pembelajaran yang dilakukan para peneliti terkadang dimodifikasi dengan 
menghilangkan tahap penyebaran (dissemination) karena tujuan penelitian pengembangan media pembelajaran adalah mengembangkan media pembelajaran yang baik. Menguji kelayakan media dalam lingkup yang besar membutuhkan biaya yang cukup besar sehingga keterbatasan biaya peneliti menjadi faktor penghambat dalam melaksanakan tahap penyebaran. Menurut Trianto (2012) adapun prosedur penelitian dan pengembangan modul kimia berbasis POE telah dijelaskan pada Gambar 1.

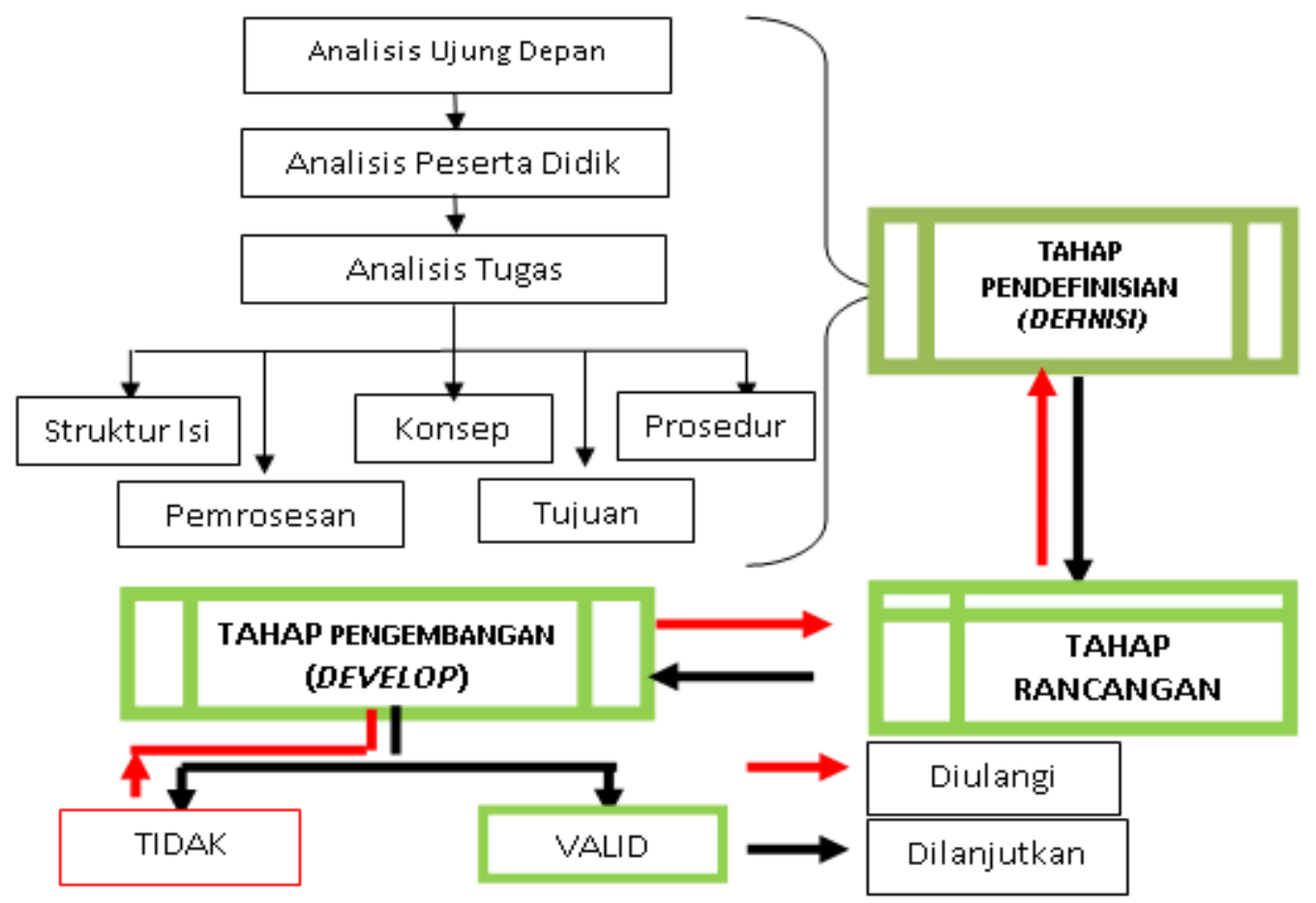

Gambar 1. Prosedur pengembangan model 4-D

Subjek penelitian yaitu dua orang validator yang terdiri dari dua orang ahli materi (Dosen Pendidikan Kimia Universitas Riau), responden peserta didik terdiri dari 10 orang peserta didik kelas XII MIA SMA N 5 Pekanbaru dan 10 orang peserta didik kelas XII MIA SMA N 8 Pekanbaru, dan responden guru terdiri dari 2 orang guru kimia kelas XII MIA SMA N 5 Pekanbaru dan 2 orang guru kimia kelas XII MIA SMA N 8 Pekanbaru. Sedangkan objek dalam penelitian ini adalah modul kimia berbasis POE sebagai sumber belajar kelas XII SMA/MA.

Modul kimia yang telah dikembangkan dinilai oleh validator untuk menguji kevalidan modul kimia dengan menggunakan lembar validasi. Lembar validasi disusun berdasarkan empat aspek yaitu aspek kelayakan isi, aspek kelayakan bahasa, aspek kelayakan kegrafikan, dan aspek kelayakan penyajian. 
Lembar validasi untuk validator disusun berdasarkan skala Likert dengan interval "valid" samai "tidak valid". Begitu juga dengan lembar tanggapan guru dan peserta didik menggunakan skala Likert

Tabel 1. Skala Penilaian Validator

\begin{tabular}{cl}
\hline Persentase & \multicolumn{1}{c}{ Keterangan } \\
\hline $80,00-100$ & Sangat Baik / Sangat Valid / Sangat Layak \\
$60,00-79,99$ & Baik / Valid / Layak \\
$50,00-59,99$ & Kurang Baik / Kurang Valid / Kurang Layak \\
$0-49,99$ & Tidak Baik \\
\hline
\end{tabular}

(Riduan, 2012)

\section{HASIL DAN PEMBAHASAN}

Penelitian pengembangan ini menghasilkan produk berupa modul kimia berbasis $P O E$ pada pokok bahasan Sifat Koligatif Larutan. Modul berbasis $P O E$ telah melewati tahap validasi oleh dosen ahli kimia dan telah diuji coba kepraktisannya oleh pengguna (guru dan peserta didik).

Rancangan awal modul yang telah disusun dikonsultasikan dengan dua orang dosen pembimbing untuk mendapat saran dan perbaikan. Revisi dari dosen pembimbing selesai, kemudian diseminarkan dan dilakukan penilaian oleh validator dan uji coba kepraktisan oleh pengguna (guru dan peserta didik).

Tahap pengembangan dilakukan setelah melewati tahap perancangan. Hasil dari tahap Pengembangan (Develop) adalah modul berbasis Predict, Observe, and Explain pada pokok bahasan Sifat Koligatif Larutan yang valid berdasarkan ahli dan praktis berdasarkan respon pengguna (guru dan peserta didik).

1) Hasil Validasi Produk

Tahap validasi bertujuan untuk memperoleh saran, masukan, dan evaluasi terhadap modul yang disusun. Validasi modul dilakukan oleh 2 orang validator, yaitu dosen Program Studi Pendidikan Kimia, Fakultas Keguruan dan Ilmu Pendidikan, Universitas Riau. Validasi dilakukan sebanyak dua kali pada masing-masing validator dan digunakan hasil validasi kedua sebagai data yang dianalisis untuk masing-masing aspek. Saat proses validasi, peneliti bersama validator melakukan diskusi untuk menyempurnakan modul yang telah dikembangkan. Saran dan masukan yang diberikan oleh masing-masing validator dijadikan acuan dalam 
melakukan perbaikan (revisi) modul sehingga menghasilkan modul Sifat Koligatif Larutan berbasis $P O E$ dengan kriteria valid.

Setiap validator menilai keseluruhan aspek yang terdapat di dalam lembar validasi. Skor tertinggi diperoleh pada aspek kelayakan bahasa dengan skor 100\%, sedangkan skor terendah diperoleh pada aspek kelayakan isi dengan skor 91,07\%.

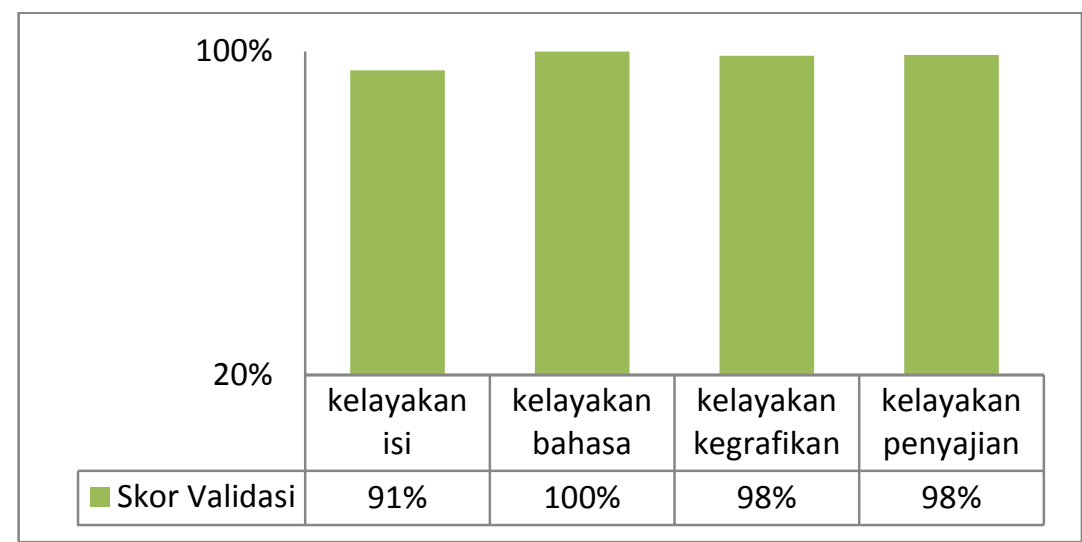

Gambar 1: Diagram Rekapitulasi Skor Rata-Rata Penilaian Aspek Validasi

a. Aspek kelayakan isi

Aspek kelayakan isi merupakan penilaian terhadap isi modul, yang memiliki 7 komponen penilaian, yaitu kelengkapan materi; keluasan materi; kedalaman materi; keakuratan konsep, prinsip, fakta, data, dan contoh; penalaran, keterkaitan, komunikasi (write and talk), serta penerapan; kemenarikan materi; keakuratan soal, gambar, diagram, ilustrasi,notasi, simbol, ikon dan acuan pustaka.

Skor rata-rata validasi aspek kelayakan isi adalah $91,07 \%$ termasuk dalam kategori valid. Terdapat 3 komponen yang mendapatkan nilai persentase rata-rata100\% (kelengkapan materi; keluasan materi; kedalaman materi), 3 komponen mendapatkan nilai persentase rata-rata87,5\% (keakuratan konsep, prinsip, fakta, data, dan contoh; keakuratan soal, gambar, diagram, ilustrasi,notasi, simbol, ikon dan acuan pustaka; Kemenarikan materi) dan 1 komponen mendapatkan nilai persentase rata-rata $75 \%$ (penalaran, keterkaitan, komunikasi (write and talk), serta penerapan) dari validator.

Menurut penilaian validator, penyajian materi tiap pertemuan dalam modul sesuai dengan KD. Kebenaran konsep dan kesesuaian materi dengan kompetensi dasar dimaksudkan agar peserta didik tidak merasa ragu ketika 
melaksanakan pembelajaran dengan modul pembelajaran sifat koligatif larutan berdasarkan pendapat Agung Chandra Yuda (2014).

b. Aspek Kelayakan Penyajian

Penilaian terhadap aspek kelayakan penyajian memiliki terhadap 7 komponen penilaian, yaitu penilaian terhadap sistematika penyajian sesuai dengan tahapan model POE; keruntutan penyajian; memuat petunjuk penggunaan modul, glosarium, daftar pustaka, dan rangkuman; penyajian bagian pendahuluan; penyajian bagian isi; dan penyajian bagian penutup.

Skor rata-rata validasi aspek kelayakan penyajian adalah 98,21\% termasuk dalam kategori valid dengan 6 komponen mendapat skor $100 \%$ dan 1 komponen mendapat skor 87,5\%. Validator memberikan penilaian bahwa materi pembelajaran yang terdapat pada modul sesuai dengan tahapan model pembelajaran POE serta telah menyajikan rangkuman pembelajaran yang tepat.

Penyusunan modul sesuai dengan kriteria Self Instructional oleh Depdiknas yang menyatakan bahwa modul harus berisi rangkuman materi pembelajaran, instrumen penilaian, soal-soal latihan serta bahasa yang sederhana dan komunikatif sehingga mampu membelajarkan peserta didik secara mandiri

c. Aspek Kelayakan Bahasa

Aspek kelayakan bahasa merupakan penilaian terhadap penggunaan bahasa dalam modul yang memiliki 4 komponen penilaian, yaitu bahasa yang digunakan lugas; penggunaan bahasa yang komunikatif, dialogis dan interaktif.; kesesuaian dengan tingkat perkembangan peserta didik, keruntutan dan keterpaduan alur pikir ; dan penggunaan istilah, simbol, atau ikon. Skor rata-rata penilaian oleh validator pada aspek ini adalah $100 \%$ dengan kategori valid. Validator memberikan penilaian bahwa struktur kalimat dalam modul tepat, efektif, dan istilah yang digunakan sudah baku serta modul telah sesuai dengan kriteria user friendly artinya memuat instruksi dan paparan informasi yang bersifat membantu dan bersahabat dengan pemakainya.

d. Aspek Kelayakan Kegrafikan

Aspek kelayakan kegrafikan merupakan penilaian terhadap ukuran modul; tata letak modul; warna dalam modul; penempatan dalam modul; spasi dalam modul; dan penggunaan variasi dalam modul. 
Validator memberikan penilaian terhadap aspek kelayakan kegrafikan dengan skor rata-rata $97,91 \%$ dengan kategori valid. Validator menilai bahwa ilustrasi/gambar yang disajikan dalam modul jelas dan berhubungan dengan konsep. Modul yang dikembangkan menggunakan gambar berwarna dan menarik. Penyajian modul yang berwarna bertujuan agar modul mempunyai daya tarik untuk dibaca. Penggunaan warna pada penyajian modul selaras dengan pendapat Ashyar, untuk membangun kemenarikan pada media bahkan dapat mempertinggi realisme dan menciptakan respon emosional diperlukan warna.

2) Hasil Uji Coba Kepraktisan

\section{a. Respon Guru}

Modul diuji kepraktisan penggunaannya oleh 2 orang guru bidang studi kimia dari SMAN 5 Pekanbaru dan 2 orang guru bidang studi kimia dari SMA 8 Pekanbaru. Guru yang memberikan respon terlebih dahulu diberikan modul untuk dipelajari. Setelah mempelajari modul secara keseluruhan, guru memberikan penilaian terhadap modul dengan menggunakan angket respon guru

Respon guru menggunakan skala Likert berbentuk pilihan ganda dengan 5 pilihan. Pernyataan paling positif mendapatkan skor tertinggi, seterusnya hingga pernyataan paling negatif mendapatkan skor terendah. Skala Likert digunakan pada kuesioner respon guru agar penilaian yang diberikan lebih detail. Skor rata-rata respon guru terhadap modul adalah 93,667\% artinya dapat digunakan tanpa revisi.

b. Respon Peserta Didik

Uji coba terbatas pada peserta didik dilakukan untuk menilai aspek kepraktisan penggunaan modul kimia berbasis POE yang dikembangkan. Uji coba dilakukan terhadap 10 orang peserta didik XII MIA SMAN 5 Pekanbaru dan 10 orang peserta didik XII MIA SMAN 8 Pekanbaru. Peserta didik yang menjadi responden adalah peserta didik yang telah mempelajari pokok bahasan Sifat Koligatif Larutan.

Uji coba dilakukan dengan terlebih dahulu melakukan sosialisasi mengenai modul dan strategi Predict, Observe, and Explain kepada peserta didik. Setiap peserta didik diberikan satu eksamplar modul untuk dibaca dan 
dipelajari. Peserta didik diberikan kuesioner respon untuk melakukan penilaian terhadap modul, setelah membaca modul secara keseluruhan.

Persentase rata-rata tanggapan peserta didik terhadap modul adalah $89,53 \%$ artinya modul dapat digunakan dengan baik.

\section{KESIMPULAN}

Berdasarkan hasil penelitian dan pembahasan dapat disimpulkan bahwa modul kimia berbasis POE (Predict, Observe, and Explain) pada materi sifat koligatif larutan sebagai sumber belajar peserta didik kelas XII SMA/MA yang telah dikembangkan valid berdasarkan aspek kelayakan isi, kebahasaan, penyajian, dan kegrafisan dengan persentase rata-rata validasi 96,7975\%, mendapat skor rata-rata 93,66\% dari guru yang dapat digunakan tanpa revisi dan mendapat skor rata-rata 89,53\% dari peserta didik yang artinya dapat digunakan dengan baik.

\section{DAFTAR PUSTAKA}

Indrawati, 2009, Pembelajaran Aktif, Kreatif, Efektif, dan Menyenangkan untuk Guru, PPPTK IPA, Bandung.

Kearney, 2004, Classroom Use of Multimedia-Supported Predict-Observe-Explain Tasks in a Social Constructivist Learning Enviroment, Kluwer Academic Publishers, Research in Science Education Netherlands

Prastowo, A., 2014, Pengembangan Bahan Ajar Temati, DIVA Press Kencana Prenada Media Group, Jakarta

Rahayu, 2013, Pengembangan Perangkat Pembelajaran POE Berbantuan Media, Innovatif Journal of Curriculum and Educational Technology, 6 (1)

Riduan, 2012, Skala Pengukuran Variabel-variabel Penelitian, Alfabeta, Bandung

Tanti, A. dan Dodi., 2016, Pengembangan Modul Berbasis POE pada Materi Usaha dan Energi, Universitas Muhammadiyah Metro

Trianto, 2012, Mendesain Model Pembelajaran Inovatif-Progresif, Kencana, Jakarta

Warsono, 2012, Peningkatan Hasil Belajar Siswa Melalui Pendekatan Keterampilan Sains Berorientasi Predict, Observe and Explain, Jurnal Inovasi Pendidikan Kimia. 3 (1) 
Widyaningrum, 2013, Pengembangan Modul Berorientasi POE Berwawasan Lingkungan Pada Materi Pencemaran untuk Meningkatkan Hasil Belajar Peserta Didik, Jurnal Bioedukasi, 6 


\title{
PEMBELAJARAN BERBASIS PROYEK UNTUK MENINGKATKAN KETERAMPILAN PROSES SAINS DAN PENGUASAAN KONSEP SISWA SMKN KEHUTANAN PROVINSI RIAU PADA MATERI PEMISAHAN CAMPURAN \\ Sri Rahmadani ${ }^{1}$, Sri Wilda Albeta ${ }^{2)}$ \\ ${ }^{1)}$ SMKN Negeri Pertanian Terpadu Provinsi Riau \\ ${ }^{2)}$ Prodi Pendidikan Kimia FKIP Universitas Riau \\ Email: srirahmadani86@gmail.com
}

\begin{abstract}
This study aims to look at improving science process skills and mastering the concepts of students using project-based learning on mixed separation. The research method used is Weak Experimental One Group Pretest-Postest Design. The object of this research is the tenth grade students of the Riau Province Forestry Vocational High School. The object of this research is the tenth grade students of the Riau Province Forestry Vocational High School. The data analysis technique used in this study is descriptive statistical analysis, namely by calculating the percentage aspects of student KPS (predicting, grouping, applying concepts, communicating, observing, designing experiments) which have implications for improving students' mastery of concepts. The KPS aspect of students who experienced the highest increase was the aspect of classifying by $97 \%$, while the lowest was achieved in the aspect of applying the concept by $54 \%$. There was an increase in mastery of the concept of mixed separation by $66.6 \%$ with the medium category. Thus it can be concluded that project-based learning can improve science process skills and mastery of students' concepts on mixed separation.
\end{abstract}

Key words : Project-Based Learning, science process skills, mastery of the concept, the Separation of Mixtures Study.

\footnotetext{
Abstrak

Penelitian ini bertujuan untuk melihat peningkatan keterampilan proses sains dan penguasaan konsep siswa menggunakan pembelajaran berbasis proyek pada materi pemisahan campuran. Metode yang digunakan adalah Weak Experimental One Group Pretest-Postest Design. Objek penelitian adalah siswa kelas X SMKN Kehutanan
} 
Provinsi Riau. Teknik analisis data yang digunakan adalah analisis statistik deskriptif, dengan cara menghitung persentase aspek keterampilan proses sains siswa (memprediksi, mengelompokkan, menerapkan konsep, berkomunikasi, observasi, merancang percobaan) yang berimplikasi pada peningkatan penguasaan konsep siswa. Aspek keterampilan proses sains siswa yang mengalami peningkatan tertinggi adalah aspek mengelompokkan sebesar 97\%, dan terendah dicapai pada aspek menerapkan konsep sebesar 54\% serta peningkatan penguasaan konsep pemisahan campuran sebesar $66,6 \%$ dengan kategori sedang. Dapat disimpulkan bahwa pembelajaran berbasis proyek dapat meningkatkan keterampilan proses sains dan penguasaan konsep siswa pada materi pemisahan campuran.

Kata Kunci: Pembelajaran berbasis proyek, keterampilan proses sains, penguasaan konsep, materi pemisahan campuran.

\section{PENDAHULUAN}

Ilmu Pengetahuan Alam (IPA) berkaitan dengan cara mencari tahu tentang gejala alam secara sistematis, sehingga IPA bukan hanya kumpulan penguasaan pengetahuan berupa fakta-fakta, konsep-konsep, atau prinsip-prinsip saja, tetapi juga merupakan suatu proses penemuan. Pendidikan IPA diharapkan dapat menjadi wahana bagi peserta didik untuk mempelajari diri sendiri dan alam sekitar, serta prospek pengembangan lebih lanjut dalam menerapkannya dalam kehidupan sehari-hari (Trianto, 2010). Kimia merupakan ilmu yang termasuk rumpun IPA, oleh karenanya kimia mempunyai karakteristik sama dengan IPA. Hakikat ilmu kimia sebagai bagian dari IPA mencakup dua hal yang tidak terpisahkan, yaitu kimia sebagai produk dan kimia sebagai proses (Alman, 2010).

Kurikulum Tingkat Satuan Pendidikan menyebutkan bahwa pembelajaran kimia bertujuan untuk memperoleh pengalaman dalam menerapkan metode ilmiah melalui percobaan atau eksperimen, dimana peserta didik melakukan pengujian hipotesis dengan merancang percobaan melalui pemasangan instrumen, pengambilan, pengolahan dan penafsiran data, serta menyampaikan hasil percobaan secara lisan dan tertulis. Perubahan penekanan dari perolehan pengetahuan kepada perolehan sains itu karena adanya asumsi bahwa belajar yang terbaik adalah melalui pengalaman (Arifin et.al, 2000). 
Keterampilan Proses Sains (KPS) mendukung terciptanya kimia sebagai proses dan produk. KPS menuntut siswa berpikir dan bertindak untuk menghadapi atau merespon masalah-masalah yang ada di lingkungan. Jadi, kimia sebagai proses menyangkut proses atau cara kerja untuk memperoleh hasil (produk) inilah yang kemudian dikenal sebagai proses ilmiah. Merujuk pada pernyataan itu, maka keterampilan proses sains dipandang sebagai keterampilan yang sangat penting dimiliki oleh setiap siswa untuk memperoleh pengetahuan sains. Dengan mengembangkan keterampilan proses, anak akan mampu menemukan dan mengembangkan sendiri fakta dan konsep serta menumbuhkan dan mengembangkan sikap dan nilai yang dituntut (Semiawan et.al, 2003)

Keterampilan Proses sains juga mendukung tujuan pembelajaran kimia di SMK. Salah satu tujuan mata pelajaran kimia di SMK yaitu menerapkan metode ilmiah melalui percobaan atau eksperimen, dimana peserta didik melakukan pengujian hipotesis dengan merancang percobaan melalui pemasangan instrumen, pengambilan, pengolahan dan penafsiran data, serta menyampaikan hasil percobaan secara lisan dan tertulis. Implikasinya adalah pembelajaran kimia di SMK hendaknya bersifat kontekstual, aplikatif dan terintegrasi dengan bidang keahliannya.

Fakta di SMKN Kehutanan Pekanbaru memperlihatkan bahwa dalam mempelajari sains, siswa cenderung lebih menghafal konsep, teori, dan prinsip tanpa memaknai proses perolehannya. KSP belum terlihat pada pembelajaran di SMKN Kehutanan. Selama pembelajaran di kelas, siswa tidak berperan aktif. Siswa hanya memperhatikan dan mendengarkan penjelasan materi serta menghafalnya saja tanpa diberikan kesempatan untuk mencoba menemukan sendiri pengetahuan tersebut. Selain itu, cara mengajar guru hanya terpaku pada buku saja tanpa menghubungkannya dengan pengetahuan dan pengalaman siswa dalam kehidupan sehari-hari sehingga relevansi pendidikan kimia dengan kebutuhan lingkungan siswa tidak tercapai.

Permasalahan keterampilan proses sains juga menjadi salah satu penyebab yang mempengaruhi kemampuan berpikir kreatif siswa. Penerapan keterampilan proses sains menjadi salah satu pilihan dalam pembelajaran untuk meningkatkan kreativitas siswa. KPS terdiri dari beberapa aspek yang harus dilewati dan dikuasai oleh siswa yaitu memprediksi, mengelompokkan, menerapkan konsep, berkomunikasi, observasi dan merancang percobaan. Seorang guru harus bisa memilih serta menerapkan model 
pembelajaran yang tepat untuk dapat mengembangkan dan meningkatkan keterampilan serta kemampuan berpikir siswa dalam pengetahuannya. Model pembelajaran merupakan suatu pola yang digunakan sebagai pedoman dalam merencanakan pembelajaran di kelas atau pembelajaran dalam tutorial dan untuk menentukan perangkat-perangkat pembelajaran seperti buku, film, komputer, kurikulum, dan lainlain.

Berdasarkan penjelasan tersebut, maka diperlukan suatu pembelajaran yang dapat mengembangkan KPS serta penguasaan konsep siswa. Model pembelajaran berbasis proyek merupakan model pembelajaran yang berpusat pada keaktifan siswa (student center learning), guru belajar dari dan bersama siswa. Selama pembuatan proyek, siswa bisa melatih dan mengembangkan keterampilan proses sains mereka yaitu seperti mengamati, menggunakan alat dan bahan, menginterpretasikan, merencanakan proyek, menerapkan konsep, mengajukan pertanyaan dan berkomunikasi dengan baik.

Pembelajaran yang memungkinkan terlaksananya hal-hal tersebut salah satunya pembelajaran dengan model proyek. Adapun yang dimaksud dengan pembelajaran proyek ialah salah satu cara pemberian pengalaman belajar dengan menghadapkan anak dengan persoalan sehari-hari yang harus dipecahkan secara berkelompok (Wena, 2009). Semiawan (dalam Wena, 2009) mengatakan bahwa sebelum melaksanakan proyek dalam pembelajaran, siswa harus telah memiliki pengetahuan awal yang berkaitan dengan tugas-tugas yang dikerjakan.

Pembelajaran berbasis proyek sebagai salah satu metode pembelajaran baru dan sebagai asesmen alternatif telah banyak dikembangkan, diantaranya oleh Sola dan Ojo (2007) yang menerapkan pembelajaran proyek dalam praktikum pemisahan campuran untuk melihat peningkatan hasil belajar siswa. Maros (2004), Adami (2006), Butter (2009), serta Mascotti dan Warner (2010) mengembangkan metode proyek untuk mengukur penguasaan konsep. Morgil (2008), menerapkannya dalam melihat sikap siswa terhadap kimia. Purnamasari (2011), menerapkannya untuk meningkatkan motivasi belajar siswa SMKN pada pembelajaran pengolahan makanan. Hal ini dapat bermanfaat bagi mereka dalam memperoleh "life skills" yang sangat penting untuk bekal kehidupannya di masa depan ketika mereka dihadapkan pada masalah-masalah lain. Karakteristik ini menjadikan hasil pembelajaran dalam sains bukan hanya sekedar mengetahui sekumpulan pengetahuan yang berupa fakta, konsep, prinsip atau teori saja, 
tetapi diharapkan dapat menjadi wahana bagi peserta didik untuk mempelajari diri sendiri dan alam sekitarnya serta prospek pengembangan berbagai kemampuan atau keterampilan lebih lanjut. Hal ini sejalan dengan tuntutan yang tercantum dalam Standar Kompetensi Lulusan (SKL) kimia di SMK.

Materi pemisahan campuran dalam mata pelajaran kimia di SMK, termasuk ke dalam materi yang penting untuk dikuasai siswa baik secara konseptual maupun secara praktikal. Materi ini sangat mendukung bidang keahlian siswa, sehingga dalam proses belajar mengajar guru diharapkan mampu membantu siswa untuk memahami materi sekaligus memfasilitasi siswa agar mampu mempraktekkannya secara langsung dan kontekstual sesuai dengan bidang keahliannya. Materi pemisahan campuran berkenaan dengan materi dasar dan integrasi, filtrasi, kristalisasi, kromatrografi dan distilasi. Implikasinya, metode proyek merupakan metode yang diduga kuat relevan untuk digunakan dalam pembelajaran pada konsep pemisahan campuran.

\section{METODE PENELITIAN}

Metode penelitian yang digunakan adalah Weak Experimental. Metode tersebut digunakan karena metode ini merupakan metode yang paling sesuai dengan kondisi subjek penelitian, dimana kelas yang diteliti hanya satu kelas dan tidak menggunakan kelas pembanding.

Desain yang digunakan dalam penelitian ini adalah One Group Pre-test-Postest Design (Frankel dan Wallen, 2008). Desain ini digunakan untuk penentuan peningkatan penguasaan konsep dan peningkatan KPS. Materi pemisahan campuran dilakukan dengan 3x pertemuan.

Subjek dalam penelitian ini adalah siswa kelas X SMKN Kehutanan Provinsi Riau pada semester II tahun ajaran ajaran 2011/ 2012 yang berjumlah 30 orang. Pemilihan kelas $\mathrm{X}$ sebagai subjek penelitian dilakukan atas pertimbangan bahwa materi pemisahan campuran dipelajari di kelas $\mathrm{X}$, ini berdasarkan sebaran KD yang disusun oleh pihak sekolah.

Instrumen yang digunakan untuk memperoleh data dalam penelitian adalah tes tertulis pilihan ganda yang digunakan untuk mengukur penguasaaan konsep siswa dan soal essay yang digunakan untuk mengukur keterampilan proses sains siswa. Adapun alur dari penelitian pembelajaran berbasis proyek ini dapat dilihat pada Gambar 1. 


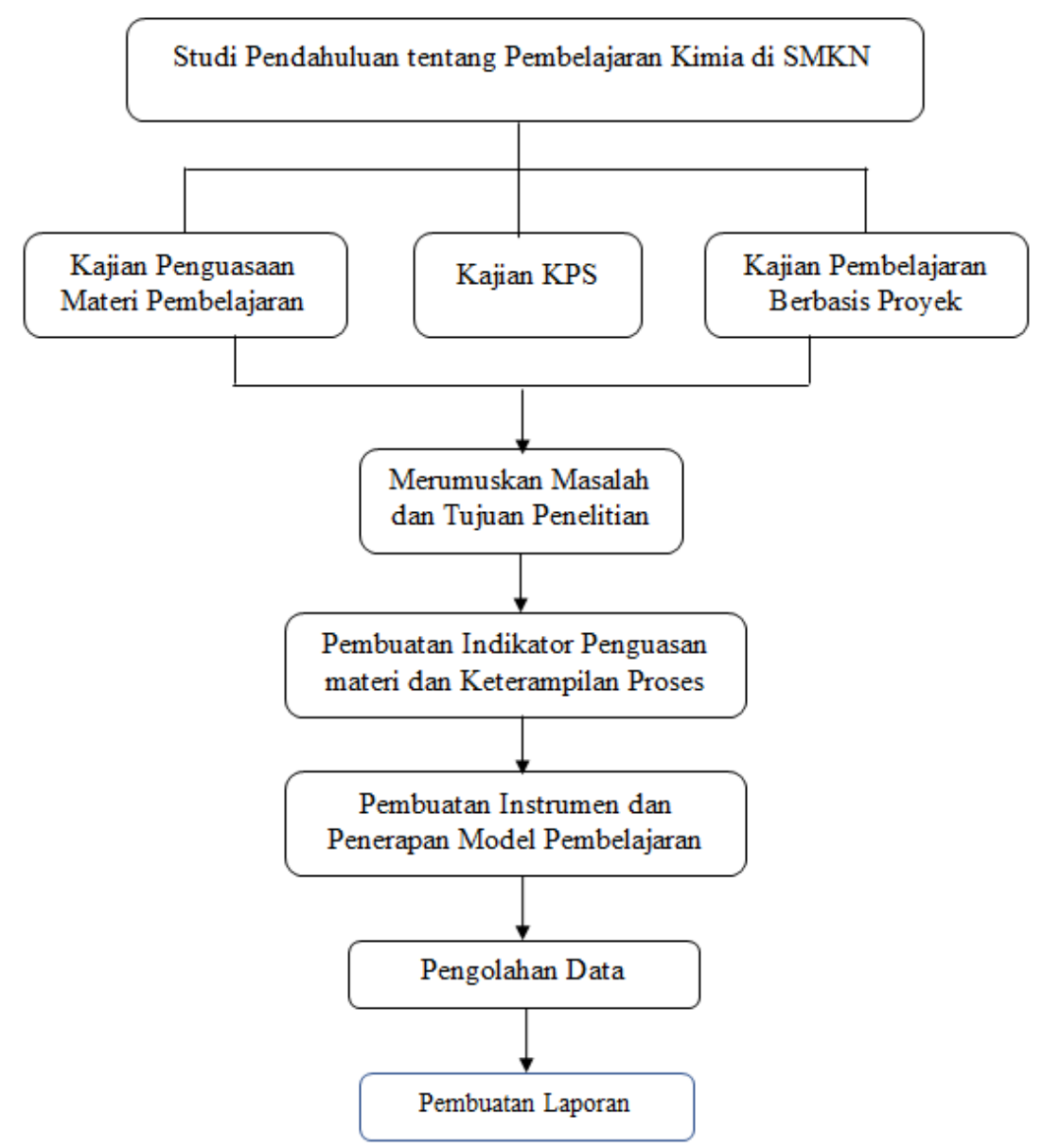

Gambar 1. Alur penelitian pembelajaran berbasis proyek

\section{Analisis data}

Data penelitian berupa hasil tes tertulis dianalisis melalui tahapan berikut:

a) Menentukan skor dari setiap jawaban hasil tes (pre-test dan post-test)

b) Menghitung skor total tiap siswa dan skor tiap butir soal.

c) Menghitung nilai pre-test dan post-test setiap siswa dengan rumus:

$$
\text { Nilai siswa }=\frac{\text { Skor mentah }}{\text { Skor maksimal }} \times 100
$$

d) Menghitung persentase KPS dan peningkatan penguasaan konsep siswa yang terjadi sebelum dan sesudah pembelajaran dihitung dengan menggunakan gain yang dinormalisasi yaitu denganrumus $g$ faktorsebagai berikut: 


$$
\text { Persentase }<g>=\frac{<S_{\text {post }}>-<S_{\text {pre }}>}{<S_{\text {maks }}>-<S_{\text {pre }}>} \text { X } 100 \%
$$

Keterangan:

$\langle g\rangle \quad=$ rata-rata gain yang dinormalisasi

$\left\langle\mathrm{S}_{\text {post }}\right\rangle=$ nilai post-test

$\left\langle\mathrm{S}_{\mathrm{pre}}\right\rangle \quad=$ nilai pre-test

$\left\langle\mathrm{S}_{\text {maks }}\right\rangle=$ nilai maksimum ideal

Untuk mengkategorikan persentase $\langle g\rangle$ penguasaan konsep siswa digunakan pengkategorian yang dapat dilihat pada Tabel 1.

Tabel 1. Pengkategorian Persentase $\langle\mathrm{g}\rangle$

\begin{tabular}{cc}
\hline Persentase & Kategori \\
\hline$\%<g>>70,0$ & Tinggi \\
\hline $30,0 \leq \%<g>\leq 70,0$ & Sedang \\
\hline$\%<g><30,0$ & Rendah \\
\hline
\end{tabular}

\section{HASIL DAN PEMBAHASAN}

Pada bagian ini akan disajikan hasil pengolahan data berkenaan dengan penerapan pembelajaran berbasis proyek terhadap peningkatan KPS dan penguasaan konsep siswa dan pembahasannya.

HASIL

\section{Penguasaan KPS}

Analisis data KPS dilakukan untuk mengetahui peningkatan KPS siswa pada pertemuan ke 1 dan pertemuan ke 3. Pada pertemuan ke 2 materi pemisahan campuran berkaitan dengan teori kromatografi dan distilasi, pada topik ini tidak dilakukan penilaian KPS. Pada Gambar 2 dapat dilihat setiap aspek KPS pada pertemuan ke-1 dan pertemuan ke-3. 


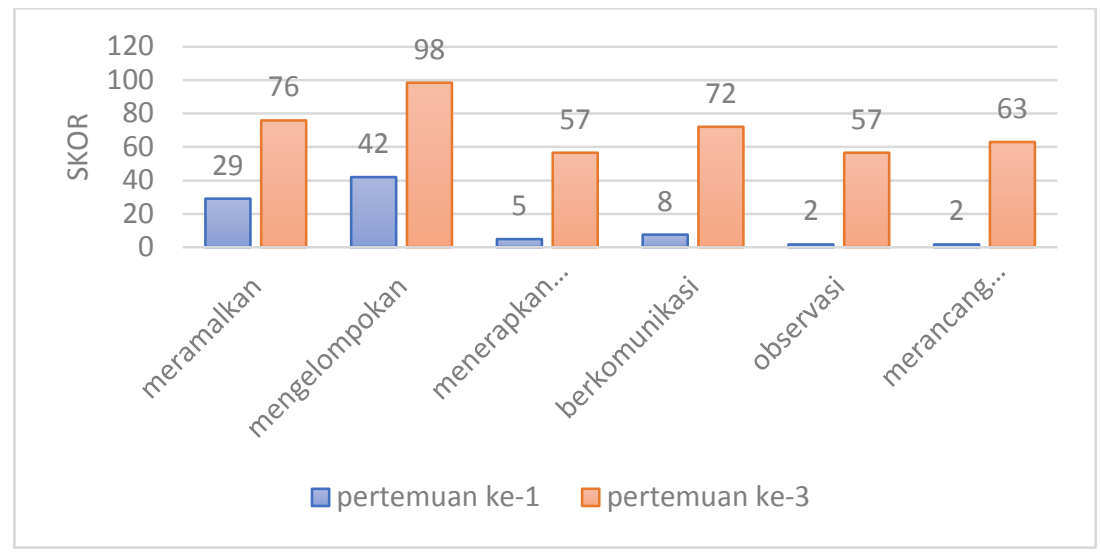

Gambar 2. Grafik Peningkatan KPS Siswa

Peningkatan KPS siswa secara detail dapat dikelompokkan untuk setiap jenis keterampilan proses sains yaitu, keterampilan memprediksi, mengelompokkan, menerapkan konsep, berkomunikasi, observasi, dan merancang percobaan. Presentase peningkatan KPS terlihat pada Gambar 3.

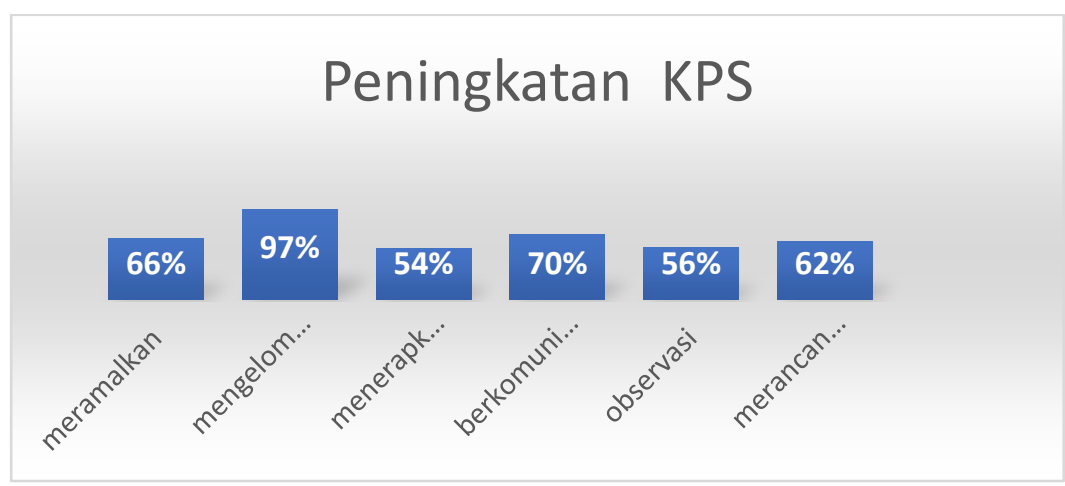

Gambar 3. Persentase Peningkatan KPS

Secara lebih khusus, nilai rata-rata peningkatan keterampilan proses sains siswa melalui perhitungan untuk masing-masing aspek KPS akan dirinci lebih dalam untuk perolehan siswa berdasarkan kategori tinggi, sedang dan rendah yang dapat dilihat pada Tabel 3.

Tabel 3. Skor Observasi Aspek KPS

\begin{tabular}{lll}
\hline Aspek KPS & Kategori & Presentase Siswa \\
\hline \multirow{2}{*}{ Memprediksi } & Tinggi & $46,7 \%$ \\
\cline { 2 - 3 } & Sedang & $26,7 \%$ \\
\cline { 2 - 3 } & Rendah & $26,7 \%$ \\
\hline
\end{tabular}




\begin{tabular}{lll}
\hline Aspek KPS & Kategori & Presentase Siswa \\
\hline \multirow{2}{*}{ Mengelompokkan } & Tinggi & $70,0 \%$ \\
\cline { 2 - 3 } Menerapkan Konsep & Sedang & $3,3 \%$ \\
\cline { 2 - 3 } & Rendah & $26,7 \%$ \\
\cline { 2 - 3 } Berkomunikasi & Sedang & $30,0 \%$ \\
\cline { 2 - 3 } & Rendah & $43,3 \%$ \\
\hline \multirow{3}{*}{ Observasi } & Tinggi & $26,7 \%$ \\
\cline { 2 - 3 } & Sedang & $43,3 \%$ \\
\cline { 2 - 3 } & Rendah & $43,3 \%$ \\
\hline \multirow{2}{*}{ Merancang Percobaan } & Tinggi & $13,3 \%$ \\
\cline { 2 - 3 } & Sedang & $36,7 \%$ \\
\cline { 2 - 3 } & Rendah & $43,3 \%$ \\
\cline { 2 - 3 } & Tinggi & $20,0 \%$ \\
\cline { 2 - 3 } & Redang & $50,0 \%$ \\
\hline & & $26,7 \%$ \\
\hline
\end{tabular}

\section{Penguasaan Konsep Pemisahan Campuran}

Untuk mengetahui apakah penerapan pembelajaran proyek memberikan pengaruh terhadap penguasaan konsep siswa pada pemisahan campuran, maka dilakukan analisis data pre-test dan post-test yang diperoleh siswa, kemudian menentukan peningkatan penguasaan konsep melalui perhitungan $\langle\mathrm{g}\rangle$. Berdasarkan hasil pengolahan data tes penguasaan konsep siswa, secara umum dapat ditunjukkan pada Gambar 4.

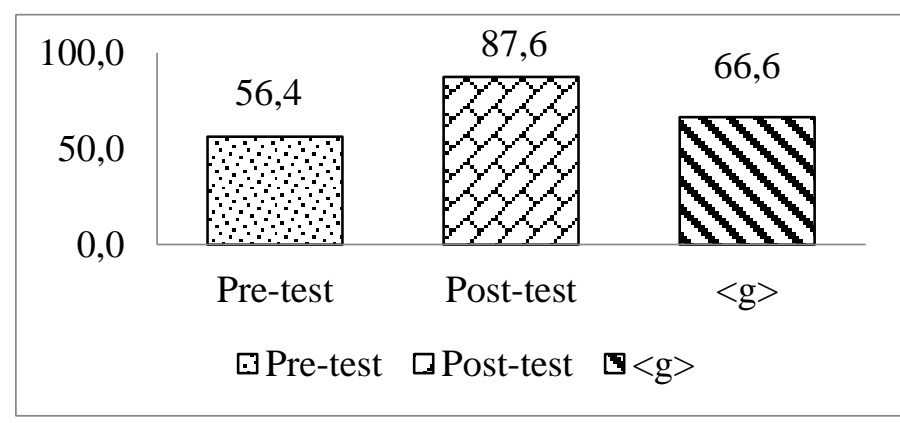

Gambar 4. Penguasaan Konsep Siswa secara Keseluruhan sebelum (pre test) dan sesudah (post-test) pembelajaran. 
Gambar 4 menunjukkan nilai rata-rata pre-test, nilai rata-rata post-test, dan persentase $\langle\mathrm{g}\rangle$ penguasaan konsep yang dicapai siswa pada materi pemisahan campuran dengan penerapan pembelajaran berbasis proyek. Pada tes awal, siswa memperoleh nilai rata-rata sebesar 56,4. Setelah proses belajar-mengajar berlangsung penguasaan konsep siswa cenderung meningkat. Hal ini terlihat dari nilai rata-rata posttest penguasaan konsep yang diperoleh oleh siswa yaitu sebesar 87,6. Peningkatan penguasaan konsep siswa sebelum dan setelah pembelajaran sangat erat kaitannya dengan $\langle\mathrm{g}\rangle$. Hal ini menunjukkan bahwa penguasaan konsep siswa secara keseluruhan pada materi pemisahan campuran meningkat dengan kategori sedang setelah pembelajaran berbasis proyek. Lebih rinci, dapat dilihat pada Tabel 4.

Tabel 4. Kategori $(\langle\mathrm{g}\rangle)$ pada penguasaan konsep

\begin{tabular}{lll}
\hline Sub konsep & Kategori $\langle$ g $>$ & Presentase Siswa \\
\hline \multirow{2}{*}{ Dasar dan integrasi } & Tinggi & $50 \%$ \\
\cline { 2 - 3 } & Sedang & $33 \%$ \\
\cline { 2 - 3 } Filtrasi & Rendah & $17 \%$ \\
\hline \multirow{3}{*}{ Kristalisasi } & Tinggi & $37 \%$ \\
\cline { 2 - 3 } & Sedang & $10 \%$ \\
\cline { 2 - 3 } & Rendah & $53 \%$ \\
\hline \multirow{3}{*}{ Kromatografi } & Tinggi & $53 \%$ \\
\cline { 2 - 3 } & Sedang & $7 \%$ \\
\cline { 2 - 3 } & Rendah & $40 \%$ \\
\hline Distilasi & Tinggi & $50 \%$ \\
\cline { 2 - 3 } & Sedang & $37 \%$ \\
\cline { 2 - 3 } & Rendah & $57 \%$ \\
\hline & Tinggi & $43 \%$ \\
\cline { 2 - 3 } & Sedang & $0 \%$ \\
\cline { 2 - 3 } & Rendah & $13 \%$ \\
\hline & & $37 \%$ \\
\hline
\end{tabular}

\section{PEMBAHASAN}

Berdasarkan hasil penelitian di atas dapat terlihat bahwa penerapan pembelajaran berbasis proyek mampu meningkatkan penguasaan konsep siswa secara 
keseluruhan. Walaupun demikian masih terdapat 2-3 orang siswa yang tidak mengalami peningkatan secara signifikan. Nilai mereka hanya meningkat 10-15 poin, sedangkan siswa yang lainnya mengalami peningkatan secara siknifikan. Hal ini terjadi karena faktor dari individu itu sendiri, seperti tidak fokus saat belajar, tidak serius dalam mengikuti pembelajaran.

Penerapan pembelajaran berbasis proyek berhasil meningkatkan penguasaaan konsep dasar pemisahan campuran, filtrasi, kristalisasi, kromatografi dan distilasi. Melalui kerja proyek siswa dapat belajar konsep utama dari suatu pengetahuan. Sejalan dengan pendapat Semiawan et.al (2003), yang mengemukakan bahwa strategi proyek bertujuan untuk memantapkan pengetahuan yang dimiliki siswa, serta memungkinkan siswa memperluas wawasan pengetahuannya.

Guru harus mampu mengaitkan pengalaman keseharian siswa atau konsepkonsep yang telah ada pada siswa untuk meningkatkan pemahaman dan penguasaan pada diri siswa, ini dapat dilakukan melalui pembelajaran berbasis proyek. Sejalan dengan pendapat Wena (2009), dalam pembelajaran berbasis proyek siswa mengalami dan belajar konsep-konsep inti suatu disiplin ilmu melalui proyek. Melalui proyeknya, siswa dapat menemukan sendiri pengetahuan tersebut. Mereka bekerja dan berusaha untuk memecahkan masalah, menerapkan dan membangun pengetahuan, menemukan sesuatu untuk dirinya dengan berusaha melalui ide-idenya.

Sejalan dengan pendapat Slavin (dalam Trianto, 2010) yang mengatakan bahwa salah satu prinsip yang paling penting dalam psikologi pendidikan adalah bahwa guru tidak hanya sekedar memberikan pengetahuan kepada siswa, namun siswa harus membangun sendiri pengetahuan di benaknya. Menurut teori konstruktivis, belajar bermakna tidak akan terwujud hanya dengan mendengarkan ceramah atau membaca buku tentang pengalaman orang lain atau buku perpustakaan. Implikasinya, melalui pembelajaran proyek guru dapat memberikan kemudahan untuk proses tersebut dengan cara memberikan kesempatan kepada siswa untuk menemukan dan menerapkan ide-ide mereka dalam menyelesaikan tugas proyek, sehingga secara tidak langsung mereka dapat menggunakan strategi mereka sendiri untuk belajar.

Dengan pembelajaran proyek, siswa dapat menerapkan pengetahuan mereka dalam kehidupan sehari-hari atau terhadap permasalahan yang terkait sehingga penguasaan mereka terhadap suatu konsep akan lebih meningkat. Hal ini sejalan dengan pendapat 
Dahar (1996) yang mengungkapkan bahwa penguasaan konsep tidak hanya terbatas mengenal konsep saja namun siswa tersebut juga harus mampu memahami suatu permasalahan baik konsep secara teori maupun penerapannya dalam kehidupan seharihari. Selain itu, peningkatan yang terjadi juga disebabkan karena pembelajaran berbasis proyek memiliki beberapa kelebihan seperti yang dikemukakan oleh Moursund (dalam Wena, 2009) antara lain sebagai berikut:

a. Meningkatkan motivasi belajar siswa terbukti dari beberapa laporan penelitian tentang pembelajaran berbasis proyek yang menyatakan bahwa siswa sangat tekun, berusaha keras untuk menyelesaikan proyek, siswa merasa lebih bergairah dalam pembelajaran, dan keterlambatan dalam kehadiran sangat berkurang.

b. Membuat siswa menjadi lebih aktif dan memecahkan problem-problem yang bersifat kompleks.

c. Memberikan kesempatan kepada siswa untuk mempraktikkan apa yang telah dipelajari.

d. Meningkatkan keterampilan siswa dalam mencari dan mendapatkan informasi.

e. Meningkatkan dan mengembangkan keterampilan komunikasi siswa.

f. Pembelajaran berbasis proyek yang diimplementasikan secara baik memberikan kepada siswa pembelajaran dan praktik dalam mengorganisasi proyek dan membuat alokasi waktu.

Aspek KPS siswa yang mengalami peningkatan tertinggi yaitu aspek mengelompokkan sebesar 97\%, sedangkan terendah dicapai pada aspek menerapkan konsep sebesar 54\%. Terjadi peningkatan penguasaan konsep pemisahan campuran sebesar 66,6\% dengan kategori sedang. Dengan demikian terlihat bahwa penguasaan konsep materi diperoleh dengan adanya proses. Pembelajaran proyek mengajarkan siswa untuk memahami dan menjalani proses, sehingga penguasaan konsep merupakan salah satu dampak dari adanya keterampilan dalam menjalankan proses tersebut. Kategori sedang $(66,6 \%)$ pada peningkatan penguasaan konsep ini juga sama halnya dengan peningkatan KPS aspek penerapan konsep (54\%) yang merupakan presentase yang terendah dari semua aspek pada KPS.

Pada penelitian ini diperoleh peningkatan KPS aspek komunikasi $70 \%$ kategori tinggi, hal ini sesuai dengan temuan Trianto (2010) yang mengatakan bahwa siswa akan lebih mudah menemukan dan memahami konsep-konsep yang sulit apabila mereka 
dapat saling mendiskusikan masalah-masalah itu dengan temannya. Hal ini berkaitan dengan keterampilan proses sains pada aspek keterampilan berkomunikasi. Untuk peningkatan KPS aspek observasi 56\% kategori sedang. Para ahli kontruktivis juga beranggapan bahwa satu-satunya alat yang tersedia bagi seseorang untuk mengetahui dan memahami sesuatu adalah inderanya karena sesorang berinteraksi dengan objek dan lingkungannya dengan melihat, mendengar, mencium, menjamah, dan merasakannya. Implikasinya, hal tersebut berkaitan dengan salah satu aspek dari KPS yakni keterampilan observasi.

Selain itu, keterampilan-keterampilan lainnya juga mendukung siswa dalam memahami suatu konsep dengan lebih baik. Sejalan dengan pendapat Semiawan et.al (2003) yang menyatakan bahwa dengan mengembangkan keterampilan proses, anak akan mampu menemukan dan mengembangkan sendiri fakta dan konsep serta menumbuhkan dan mengembangkan sikap dan nilai yang dituntut.

\section{KESIMPULAN}

Berdasarkan hasil penelitian dan analisis, dapat disimpulkan bahwa pembelajaran berbasis proyek pada materi pemisahan campuran dapat meningkatkan KPS siswa. Sejalan dengan meningkatnya KPS siswa, penerapan pembelajaran berbasis proyek berimplikasi terhadap peningkatan penguasaan konsep. Seluruh aspek dalam penguasaan konsep pada materi pemisahan campuran meningkat.

\section{DAFTAR PUSTAKA}

Adami, G, 2006, A New Project-Based Lab for Undergraduate Enviromental and Analytical Chemistry, Journal of Chemistry Education, 83 (2)

Alman, 2010, Pedoman Workshop KTSP SMKN Pertanian Terpadu Negeri Provinsi Riau_KTSP SMKN, Departemen Pendidikan Nasional

Arifin, M., Sudja, W.A., Ismail, A.K., Mulyono. dan Wahyu, W, 2000, Strategi Belajar Mengajar Kimia, Pendidikan Kimia FPMIPA UPI, Bandung

Butter, L.R, 2009, Investigation of The Use of Cucumis Sativus for Remediation of Chromium from Contaminated Environmental Matrices. An Interdiciplinary Instrumental Analysis Project, Journal of Chemistry Education, 86 (9) 
Frankel, J. P. dan Wallen N. E., 2008, How to Design and Evaluate Research in Education. New York : McGraw-Hill Companies

Morgil, I., 2008, “The Effect of Web-Based Project Applications on Students' Attitudes Towards Chemistry'. Journal of Distance Education-TODJE Volume 9.

Purnamasari, E., 2011, Upaya Peningkatan Motivasi Belajar Siswa Melalui Penerapan Metode Berbasis Proyek pada Mata Pelajaran Pengolahan Makanan di SMK Sahid Surakarta, Thesis Universitas Negeri Yogyakarta.

Maros, P.S., 2004, Class Project in Physical Organic Chemistry : The Hydrolysis of Aspirin, Journal of Chemistry Education, 81 (6)

Mascotti, D.P, dan Warner, M.J, 2010, Complementary Spectroscopic Assays for Investigating Protein-Ligand Binding Activity : A Project for The Advanced Chemistry laboratory. Journal of Chemistry Education, 87 (7)

Semiawan, C., Tangyong, A.F., Belen, S., Matahelemual, Y, 2003, Pendekatan Keterampilan Proses; Bagaimana Mengaktifkan Siswa dalam Belajar, PT. Gramedia, Jakarta

Sola dan Ojo, 2007, Effects of Project, Inquiry, and Lecture-Demonstration Teaching Methods on Senior Secondary Students' Achievement in Separation of Mixtures Practical Test, Journal of Educational Research and Review vol.2 (6)

Trianto, 2010, Model Pembelajaran Terpadu : Konsep, Strategi, dan Implementasinya dalam KTSP. Bumi Aksara, Jakarta

Wena, M, 2009, Strategi Pembelajaran Inovatif Kontemporer, Bumi Aksara, Jakarta 
PENERAPAN PEMBELAJARAN KOOPERATIF TIPE NHT UNTUK MENINGKATKAN AKTIVITAS DAN HASIL BELAJAR KIMIA SISWA PADA MATERI IKATAN KIMIA

\author{
Yandriani1 $^{1)}$, Agustini $^{2)}$ \\ ${ }^{1)}$ SMA Negeri 1 Bantan Kabupaten Bengkalis Provinsi Riau \\ ${ }^{2)}$ SMA Negeri 2 Bantan Jl. Budi Luhur Sukamaju Kabupaten Bengkalis Provinsi Riau
}

Email: yaniyandriani@gmail.com

\begin{abstract}
Learning chemistry passively, monotonously and lacking enthuasiasme is leading to low student learning outcomes. According to the results of daily tests, only a few students who achieve mastery. One reason is the teachers still use conventional methods and models. To overcome these problems, improvements were made to the application of the learning process of cooperative learning NHT (Numbered Head Together). This study aims to determine whether the application of NHT type cooperative learning can enhance the activity and student learning outcomes in chemical bonding material. This research is a classroom action research conducted in SMA Negeri 1 Bantan class X in the academic year 2014/2015. The results showed that the chemical activity and increased student learning outcomes. In the first cycle of individual student mastery of $16(59.3 \%)$ and students who did not complete as many as $11(40.7 \%)$. After the corrective actions in the second cycle, the thoroughness of individuals increased to 21 (77.7\%) students who completed and $6(22.3 \%)$ of students who did not complete, an increase of $18.4 \%$. Based on the results of this study concluded that cooperative learning $\mathrm{NH}$ could improve the activities and outcomes of learning chemistry student at the Institute of Chemistry of matter
\end{abstract}

Keyword:Activity, results learning, chemical bonding, cooperative learning, NHT

\begin{abstract}
Abstrak
Pembelajaran kimia yang pasif, monoton dan motivasi siswa rendah menyebabkan hasil belajar siswa rendah. Hasil ulangan harian siswa menunjukkan bahwa hanya beberapa siswa saja yang mencapai ketuntasan. Salah satu penyebabnya adalah guru masih menggunakan metode dan model konvensional. Untuk mengatasi masalah tersebut,
\end{abstract}


dilakukan perbaikan proses pembelajaran dengan penerapan pembelajaran kooperatif tipe NHT (Numberred Head Together). Penelitian ini bertujuan untuk mengetahui apakah penerapan pembelajaran kooperatif tipe NHT dapat meningkatkan aktivitas dan hasil belajar siswa pada materi Ikatan Kimia. Penelitian ini merupakan penelitian tindakan kelas yang dilakukan pada SMA N 1 Bantan kelas X pada tahun pelajaran 2014/2015. Hasil penelitian menunjukkan bahwa aktivitas dan hasil belajar kimia siswa meningkat. Pada siklus I ketuntasan individu siswa sebanyak $16(59,3 \%)$ dan siswa yang tidak tuntas sebanyak $11(40,7 \%)$. Setelah dilakukan tindakan perbaikan pada siklus II, ketuntasan individu meningkat menjadi $21(77,7 \%)$ siswa yang tuntas dan sebanyak $6(22,3 \%)$ siswa yang tidak tuntas, mengalami peningkatan 18,4\%. Berdasarkan hasil penelitian dapat disimpulkan bahwa pembelajaran kooperatif tipe NHT dapat meningkatkan aktivitas dan hasil belajar kimia siswa pada materi Ikatan Kimia.

Kata Kunci: Aktivitas, hasil belajar, ikatan Kimia, kooperatif learning, NHT

\section{PENDAHULUAN}

Pemilihan dan penggunaan model yang tepat dalam menyajikan suatu materi dalam proses belajar mengajar dapat membantu siswa dalam mengetahui serta memahami segala sesuatu yang disajikan guru, sehingga melalui tes hasil belajar dapat diketahui peningkatan prestasi belajar siswa. Melalui pembelajaran yang tepat, siswa diharapkan mampu memahami dan menguasai materi ajar sehingga dapat berguna dalam kehidupan nyata. Salah satu indikator keberhasilan proses belajar mengajar dapat dilihat dari prestasi belajar yang dicapai siswa (Sudjana, 2002).

Kualitas pembelajaran kimia yang masih rendah di kelas X SMA Negeri 1 Bantan dapat dilihat dari proses dan hasil belajar siswa. Kualitas hasil belajar dapat diamati dari prestasi belajar dan ketuntasan belajar siswa. Berkaitan dengan kualitas hasil belajar siswa, berdasarkan pengamatan yang dilakukan oleh guru bidang studi dalam beberapa ulangan harian, ketuntasan hasil belajar siswa untuk kelas X dalam mata pelajaran kimia masih tergolong sangat rendah dengan KKM sebesar 70. Siswa yang mencapai nilai KKM hanya beberapa orang saja. Rendahnya hasil belajar siswa tersebut diduga kuat aktivitas belajar siswa dalam proses pembelajaran sangat rendah, sehingga terlihat siswa tidak pernah siap untuk menerima materi pelajaran dalam setiap 
pertemuan. Ketidaktepatan model pembelajaran guru akan berakibat pada rendahnya aktivitas belajar dan hasil belajar siswa. Kegiatan pembelajaran kimia di SMA Negeri 1 Bantan masih terfokus pada guru, siswa pada umumnya pasif, tidak terlibat aktif dalam pembelajaran, sehingga hasil belajar siswa rendah.

Materi dalam proses pembelajaran, dapat disajikan dengan berbagai model sehingga suasana pembelajaran menjadi lebih menarik dan menyenangkan. Selama proses pembelajaran kecenderungan siswa pasif sehingga hasil belajar yang diharapkan dalam proses pembelajaran tidak tercapai secara optimal. Salah satu upaya guru untuk meningkatkan kualitas pembelajaran adalah dengan menerapkan model-model pembelajaran yang memberikan kesempatan kepada siswa secara aktif untuk mempelajari materi melalui perbuatan, mengalami sendiri, menemukan serta mengembangkan pengetahuan yang diperoleh. Dengan demikian, dalam proses pembelajaran siswa harus lebih berperan aktif dan memperoleh pengalaman belajar yang menyenangkan dan siswa akan lebih termotivasi dalam belajar. Aktifitas belajar siswa yang tinggi tersebut jelas akan mempengaruhi hasil belajar siswa. Belajar kimia memerlukan keterampilan dari seorang guru agar anak didik mudah memahami materi yang diberikan guru. Jika guru kurang menguasai strategi mengajar maka siswa akan sulit menerima materi pelajaran dengan sempurna. Guru dituntut untuk mengadakan inovasi dan berkreasi dalam melaksanakan pembelajaran, sehingga hasil belajar siswa memuaskan (Darsono, 2002).

Ilmu kimia sebagai salah satu bidang kajian Ilmu Pengetahuan Alam (IPA) sudah mulai diperkenalkan kepada siswa sejak dini. Mata pelajaran kimia menjadi sangat penting kedudukannya dalam masyarakat karena kimia selalu berada di sekitar kita dalam kehidupan sehari-hari. Kimia adalah salah satu mata pelajaran yang diuji pada ujian nasional. Namun, selama ini masih banyak siswa yang mengalami kesulitan dalam memahami dan mengikuti pelajaran kimia. Banyak siswa berpendapat bahwa kimia merupakan mata pelajaran yang sulit sehingga siswa kurang berminat dengan mata pelajaran kimia. Hal ini tidak terlepas dari materi yang dipelajari dalam kimia lebih bersifat abstrak. Kegiatan pembelajaran kimia membutuhkan model pembelajaran yang tepat sehingga tujuan pembelajaran kimia dapat tercapai dengan optimal.

Kimia merupakan ilmu yang termasuk rumpun IPA, oleh karenanya kimia mempunyai karakteristik sama dengan IPA. Karakteristik tersebut adalah objek ilmu 
kimia, cara memperoleh, serta kegunaannya. Kimia merupakan ilmu yang pada awalnya diperoleh dan dikembangkan berdasarkan percobaan (induktif) namun pada perkembangan selanjutnya kimia juga diperoleh dan dikembangkan berdasarkan teori (deduktif). Kimia adalah ilmu yang mencari jawaban atas pertanyaan apa, mengapa, dan bagaimana gejala-gejala alam yang berkaitan dengan komposisi, struktur dan sifat, perubahan, dinamika, dan energetika zat. Oleh sebab itu, mata pelajaran Kimia mempelajari segala sesuatu tentang zat yang meliputi komposisi, struktur dan sifat, perubahan, dinamika, dan energetika zat yang melibatkan keterampilan dan penalaran. Ada dua hal yang berkaitan dengan kimia yang tidak terpisahkan, yaitu kimia sebagai produk (pengetahuan kimia yang berupa fakta, konsep, prinsip, hukum, dan teori) temuan ilmuwan dan kimia sebagai proses (kerja ilmiah). Oleh sebab itu, pembelajaran kimia dan penilaian hasil belajar kimia harus memperhatikan karakteristik ilmu kimia sebagai proses dan produk (Sudarmo, 2006).

Pembelajaran kooperatif adalah metode atau model dimana siswa belajar bersama, saling menyumbangkan pikiran dan bertanggung jawab terhadap pencapaian hasil belajar individu dan kelompok. Konsep yang lebih luas meliputi semua jenis kerja kelompok termasuk bentuk-bentuk yang lebih dipimpin oleh guru atau diarahkan oleh guru. Secara umum pembelajaran kooperatif dianggap lebih diarahkan oleh guru, dimana guru menetapkan tugas dan pertanyaan-pertanyaan serta menyediakan bahanbahan dan informasi yang dirancang untuk membantu peserta didik menyelesaikan masalah yang dimaksud. Guru biasanya menempatkan bentuk ujian tertentu pada akhir tugas. Belajar secara kooperatif mampu melibatkan siswa secara aktif melalui prosesproses mentalnya dan meminimalkan adanya perbedaan-perbedaan antar individu, serta meminimalisasi pengaruh negatif yang timbul dari kondisi pembelajaran kompetitif (persaingan belajar yang tidak "sehat"). Sebagai teknologi pembelajaran, belajar kooperatif memiliki sinergisitas peluang munculnya keterampilan sosial di antara pendidikan formal dan pendidikan non-formal. Keterpaduan peluang tersebut dapat dilihat dari (1) dalam realisasi praktik hidup di luar kelas (sekolah), membutuhkan keterampilan dan aktivitas-aktivitas kolaboratif mulai dari dalam kelompok (tim) di tempat bekerja hingga ke dalam kehidupan sosial sehari-hari; (2) tumbuh dan berkembangnya kesadaran mengenai nilai-nilai interaksi sosial untuk mewujudkan pembelajaran bermakna. Tujuan pembelajaran kooperatif berbeda dengan kelompok 
konvensional yang menerapkan sistem kompetisi, di mana keberhasilan individu diorientasikan pada kegagalan orang lain. Sedangkan tujuan dari pembelajaran kooperatif adalah menciptakan situasi di mana keberhasilan individu ditentukan atau dipengaruhi oleh keberhasilan kelompoknya (Muliyati dkk, 2007).

Pembelajaran kooperatif tidak sama dengan sekedar belajar dalam kelompok. Ada unsur-unsur dasar pembelajaran kooperatif yang membedakannya dengan pembagian kelompok yang dilakukan asal-asalan. Pelaksanaan prosedur model pembelajaran kooperatif dengan benar akan memungkinkan guru mengelola kelas lebih efektif. Model pembelajaran kooperatif akan dapat menumbuhkan pembelajaran efektif. pembelajaran kooperatif tidak sama dengan sekedar belajar dalam kelompok. Ada unsur-unsur dasar pembelajaran kooperatif yang membedakannya dengan pembagian kelompok yang dilakukan asal-asalan. Pelaksanaan prosedur model pembelajaran kooperatif dengan benar akan memungkinkan guru mengelola kelas lebih efektif. (Wijayatia, dkk, 2008)

Model pembelajaran kooperatif akan dapat menubuhkan pembelajaran efektif yaitu pembelajaran yang bercirikan (1) "memudahkan siswa belajar" sesuatu yang "bermanfaat" seperti fakta, keterampilan, nilai, konsep, dan bagaimana hidup serasi dengan sesama; (2) pengetahuan, nilai, dan keterampilan diakui oleh mereka yang berkompenten menilai (Lie, 2004).

Number Head Together adalah suatu model pembelajaran yang lebih mengedepankan kepada aktivitas siswa dalam mencari, mengolah, dan melaporkan informasi dari berbagai sumber yang akhirnya dipresentasikan di depan kelas. NHT pertama kali dikenalkan oleh Spencer Kagan. Model NHT adalah bagian dari model pembelajaran kooperatif struktural, yang menekankan pada struktur-struktur khusus yang dirancang untuk mempengaruhi pola interaksi siswa. (Rofiqoh dkk, 2015)

Penelitian sebelumnya mengenai NHT pernah dilakukan oleh Muliyati, dkk (2007). Penelitian ini dilaksanakan pada semester genap tahun pelajaran 2016/2017 di SMA Negeri 1 Masamba, Kecamatan Masamba, Kabupaten Luwu - Utara. Subjek dalam penelitian ini adalah kelas XI IPA5 dengan jumlah peserta didik sebanyak 36 orang. Data-data hasil penelitian yang diperoleh menunjukkan adanya peningkatan motivasi belajar Biologi, aktivitas peserta didik dan hasil belajar Biologi peserta didik melalui penerapan model pembelajaran kooperatif tipe NHT. 
Penelitian lain mengenai NHT pernah dilakukan oleh Rofiqoh, dkk., (2015) Perolehan data respon siswa dilakukan dengan memberikan angket respon siswa kepada siswa kelas XI MIA 4 SMAN Arjasa setelah pelaksanaan kegiatan pembelajaran. Penggabungan model pembelajaran kooperatif tipe NHT disertai media monopoli games terintegrasi pendekatan problem solving sangat cocok, karena siswa akan membangun pengetahuan yang baru berdasarkan pengetahuan yang didapatkan melalui media monopoli games dengan pengetahuan sebelumnya yang sudah dimiliki. Teknik analisis data untuk hasil belajar siswa adalah dengan menggunakan aturan pihak kanan. Ada pengaruh yang signifikan penggunaan model pembelajaran kooperatif Tipe NHT disertai media monopoli games terintegrasi pendekatan Problem Solving terhadap hasil belajar fisika di SMA.

Penelitian mengenai NHT juga pernah dilakukan oleh Wijayatia, dkk., (2008). Tujuan dari penelitian ini adalah untuk mengetahui pengaruh penggunaan model pembelajaran NHT terhadap hasil belajar kimia hidrokarbon. Untuk mengetahui adanya pengaruh penggunaan model pembelajaran NHT menggunakan uji perbedaan dua ratarata (uji t). Populasi dalam penelitian ini adalah seluruh siswa kelas $X$ semester 2 SMA Negeri 15 Semarang tahun ajaran 2005/2006. Pengaruh positif yang diberikan oleh penggunaan model pembelajaran NHT mungkin disebabkan adanya variasi pembelajaran sehingga dapat menimbulkan ketertarikan, minat dan motivasi pada siswa. Simpulan yang diperoleh dari penelitian ini adalah ada pengaruh penggunaan model pembelajaran NHT terhadap hasil belajar kimia hidrokarbon.

Oleh karena itu, Penulis tertarik untuk meneliti tentang Model Kooperatif NHT pada materi ikatan ikatan kimia. Tujuan dari penelitian ini adalah (1) Untuk meningkatkan aktivitas belajar kimia siswa kelas X SMA N 1 Bantan pada materi ikatan kimia melalui penerapan pembelajaran kooperatif tipe NHT. (2) Untuk meningkatkan hasil belajar siswa kelas X SMA N 1 Bantan pada materi Ikatan Kimia.

\section{METODE PENELITIAN}

Penelitian ini merupakan penelitian tindakan kelas (PTK) yang terdiri dari 2 siklus dan dilaksanakan di kelas X SMA Negeri 1 Bantan tahun pelajaran 2014/2015. Siklus I, materi yang diajarkan adalah kestabilan unsur dan Ikatan Ionik dan pada siklus II adalah Ikatan Kovalen, Ikatan koordinasi dan ikatan logam. Subjek penelitian ini 
adalah siswa/i kelas X IPA 2 SMA Negeri 1 Bantan pada semester 1 Tahun pelajaran 2014/2015 dengan jumlah siswa/i sebanyak 27 orang yang terdiri dari 8 orang putra dan 29 orang putri.

Prosedur Penelitian Tindakan Kelas (PTK) penggunaan kooperatif tipe NHT terdiri atas beberapa tahapan, yaitu: perencanaan, pelaksanaan, pengamatan, refleksi. Adapun langkah- langkah pembelajarannya seperti berikut :

Langkah 1. Persiapan

Guru mempersiapkan rancangan pelajaran dengan membuat Skenario Pembelajaran (SP), Lembar Kerja Siswa (LKS) yang sesuai dengan model pembelajaran tipe NHT.

Langkah 2. Pembentukan kelompok

Pembentukan kelompok disesuaikan dengan model pembelajaran tipe NHT. Guru membagi para siswa menjadi beberapa kelompok yang beranggotakan 3-5 orang siswa. Guru memberi nomor kepada setiap siswa dalam kelompok dan nama kelompok yang berbeda. Penomoran adalah hal yang utama di dalam NHT, dalam tahap ini guru membagi siswa menjadi beberapa kelompok atau tim yang beranggotakan tiga sampai lima orang dan memberi siswa nomor sehingga setiap siswa dalam tim mempunyai nomor berbeda-beda, sesuai dengan jumlah siswa di dalam kelompok. Kelompok yang dibentuk merupakan percampuran yang ditinjau dari latar belakang sosial, ras, suku, jenis kelamin dan kemampuan belajar.

Selain itu, dalam pembentukan kelompok digunakan nilai tes awal (pre-test) sebagai dasar dalam menentukan masing-masing kelompok.

\section{Langkah 3. Tiap kelompok harus memiliki buku paket atau buku panduan}

Tiap kelompok harus memiliki buku paket atau buku panduan agar memudahkan siswa dalam menyelesaikan LKS atau masalah yang diberikan oleh guru.

\section{Langkah 4. Diskusi masalah}

Guru membagikan LKS kepada setiap siswa sebagai bahan yang akan dipelajari. Dalam kerja kelompok setiap siswa berpikir bersama untuk menggambarkan dan meyakinkan bahwa tiap orang mengetahui jawaban dari pertanyaan yang telah ada dalam LKS atau pertanyaan yang telah diberikan oleh guru. Pertanyaan dapat bervariasi, dari yang bersifat spesifik sampai yang bersifat umum.

Langkah 5. Memanggil nomor anggota atau pemberian jawaban

Guru menyebut satu nomor dan para siswa dari tiap kelompok dengan nomor yang sama 
mengangkat tangan dan menyiapkan jawaban kepada siswa di kelas.

\section{Langkah 6. Memberi kesimpulan}

Guru bersama siswa menyimpulkan jawaban akhir dari semua pertanyaan yang berhubungan dengan materi yang disajikan (Kusuma, dkk., 2008).

Instrumen yang digunakan dalam penelitian tindakan kelas ini berupa lembar observasi aktivitas, LKS, tes tertulis (uraian). Tes digunakan untuk mengukur kemampuan siswa dalam menguasai konsep yang diberikan. Data yang diperoleh dikelompokkan kemudian dianalisis dengan menggunakan analisis deskriptif (analisis ketuntasan belajar). Analisis ini bertujuan untuk memperlihatkan tingkat penguasaan dan ketuntasan/keberhasilan belajar siswa.

Seorang siswa dikatakan tuntas secara individu, apabila siswa tersebut memperoleh daya serap minimal 67 (kurikulum 2013), sedangkan ketuntasan klasikal sebesar $75 \%$. Persentase ketuntasan ini dihitung dengan menggunakan rumus sebagai berikut:

4. Ketuntasan Belajar Siswa Individu (KBSI), menggunakan rumus:

KBSI =

Skor Maksimal

5. Ketuntasan Belajar Siswa Klasikal (KBSK), menggunakan rumus:

KBSK = Jumlah Siswa Yang Tuntas $\times 100 \%$

Jumlah Siswa Keseluruhan

6. Daya Serap Siswa (DSS), menggunakan rumus:

DSS $=\frac{\sum \text { Skor Perolehan }}{\sum \text { Skor Maksimal }} \times 100 \%$

(Depdiknas, 2004).

Keberhasilan tindakan dilihat dari masing-masing siklus. Kriteria keberhasilan tindakan adalah terjadinya peningkatan kualitas pembelajaran, yaitu dengan meningkatnya kualitas pada indikator (1), aktivitas siswa (2) prestasi belajar siswa, terhadap model pembelajaran yang digunakan.

\section{HASIL DAN PEMBAHASAN \\ HASIL PENELITIAN}

Data hasil penelitian aktivitas belajar siswa dalam pembelajaran kooperatif tipe 
NHT ditunjukkan pada Tabel 1.

Tabel 1. Aktivitas Siswa Dalam Proses Pembelajaran Kooperatif tipe NHT

\begin{tabular}{|c|l|c|c|}
\hline \multirow{2}{*}{ NO } & \multirow{2}{*}{ Indikator } & \multicolumn{2}{c|}{ \% Aktivitas Siswa } \\
\cline { 3 - 4 } & & Siklus I & Siklus II \\
\hline 1 & Bertanya pada guru & 41 & 78 \\
\hline 2 & Menjawab pertanyaan guru & 52 & 81 \\
\hline 3 & Memberikan pendapat & 56 & 63 \\
\hline 4 & Aktif dalam diskusi & 81 & 85 \\
\hline 5 & Bekerjasama & 78 & 89 \\
\hline 6 & Presentasi Hasil Diskusi & 63 & 85 \\
\hline 7 & Menyimpulkan hasil diskusi & 74 & $80,14 \%$ \\
\hline & Total & $63,57 \%$ & 0 \\
\hline
\end{tabular}

Data pada Tabel 1 menggambarkan hasil observasi aktivitas siswa selama proses pembelajaran, dimana pada siklus I aktivitas siswa 63,57\% sedangkan pada siklus II meningkat menjadi 80,14\%. Peningkatan aktivitas siswa ditunjukkan pada Gambar 1.

Data hasil penelitian ketuntasan individu dan klasikal siswa kelas X IPA 2 Semester 1 SMAN 1 Bantan Kecamatan Bantan Tahun Pelajaran 2014/2015 dengan menerapkan model pembelajaran kooperatif tipe NHT dapat dilihat pada Tabel 2.

Tabel 2. Persentase Ketuntasan Belajar Siswa untuk Tiap Siklus

\begin{tabular}{|l|l|c|c|c|}
\hline \multirow{2}{*}{ No } & \multirow{2}{*}{ Kegiatan } & \multicolumn{3}{|c|}{ Ketuntasan Belajar } \\
\cline { 3 - 4 } & & \multicolumn{2}{|c|}{ Individu } & \multirow{2}{*}{ Klasikal } \\
\cline { 3 - 5 } & & Tuntas & Tidak Tuntas & N (\%) \\
\cline { 3 - 5 } & & $\mathrm{N}(\%)$ & $\mathrm{N}(\%)$ & $59,3 \%$ (Tuntas) \\
\hline 1 & Evaluasi (Siklus I) & $16(59,3 \%)$ & $11(40,7 \%)$ & $57,7 \%$ (Tuntas) \\
\hline 2 & Evaluasi (Siklus II) & $21(77,7 \%)$ & $6(22,3 \%)$ & 770 \\
\hline
\end{tabular}

Data pada Tabel 2 di atas mengambarkan hasil belajar setelah dilakukan perbaikan sangat mengembirakan. Pada siklus I ketuntasan individu siswa terdapat sebanyak $16(59,3 \%)$ dan siswa yang tidak tuntas $11(40,7 \%)$. Setelah dilakukan 
perbaikan tindakan pada siklus II, ketuntasan individu siswa meningkat menjadi 21 $(77,7 \%)$ siswa yang tuntas dan sebanyak $5(22,3 \%)$ siswa yang tidak tuntas, mengalami penurunan sebesar $18,4 \%$. Demikian juga halnya dengan ketuntasan klasikal. Pada siklus I hanya 59,3\% siswa yang tuntas, pada siklus II ketuntasan klasikal siswa mengalami peningkatan menjadi $77,7 \%$, meningkat sebesar $18,4 \%$.

Selanjutnya, berdasarkan pengelompokkan interval nilai hasil belajar siswa pada PBM siklus I dan II dapat dilihat pada Tabel 3:

Tabel 3. Deskripsi Hasil Pengelompokan berdasarkan Interval Nilai Hasil Belajar Siswa pada Siklus I dan II.

\begin{tabular}{|c|c|c|}
\hline \multirow{2}{*}{ Interval (skor)/ kategori } & \multicolumn{2}{|c|}{ Jumlah Siswa (persentase) } \\
\hline & Siklus I & Siklus II \\
\hline 81-100 (Sangat baik) & 8 orang $(29 \%)$ & 10 orang $(37 \%)$ \\
\hline 67-80 (Baik ) & 8 orang $(29 \%)$ & 11 orang (37\%) \\
\hline $41-66 \quad$ (Cukup) & 9 orang $(33,3 \%)$ & 6 orang $(22,2 \%)$ \\
\hline$\leq 40$ (Kurang) & 2 orang $(7 \%)$ & - \\
\hline Rata-rata daya serap & $69,7 \%$ & $74,7 \%$ \\
\hline
\end{tabular}

Data pada Tabel 3. tentang daya serap siswa pada mata pelajaran Kimia dapat dijelaskan, bahwa pada siklus I siswa yang memperoleh rentang nilai 81-100 8(29\%), tetapi setelah dilakukan perbaikan pada siklus II mengalami peningkatan yang sangat signifikan, yaitu sebanyak 10 (37\%), mengalami peningkatan sekitar (8\%). Sedangkan siswa yang memperoleh nilai $\leq 40$ pada siklus I terdapat sebanyak 2 (7\%). Setelah dilakukan perbaikan pada siklus II, siswa yang memperoleh nilai $\leq 40$ sudah tidak ada, mengalami penurunan sebesar 7\%. Sedangkan daya serap siswa pada siklus I hanya sebesar $69,7 \%$. Setelah dilakukan perbaikan pada siklus II, daya serap siswa mengalami peningkatan menjadi 74,7\%, mengalami peningkatan sebesar $5 \%$.

\section{PEMBAHASAN}

Setelah dilakukan pelaksanaan, pemantauan, evaluasi dan refleksi atas perbaikan pembelajaran Kimia melalui pembelajaran kooperatif tipe NHT materi Ikatan Kimia terhadap siswa kelas X semester 1 SMA Negeri 1 Bantan Kecamatan Bantan Tahun 
Pelajaran 2014/ 2015, diperoleh hasil observasi aktifitas belajar siswa pada siklus I masih banyak siswa yang belum mau bertanya, memberikan pendapat dan belum bisa menyimpulkan materi pembelajaran dengan baik. Hal ini mungkin dikarenakan bahwa siswa masih awam atau belum terbiasa dengan pembelajaran kooperatif tipe NHT ini. Pada siklus II, aktivitas belajar siswa dalam proses pembelajaran meningkat secara signifikan. Peningkatan aktifitas siswa dari siklus ke siklus dapat dilihat dari grafik 1. Dalam proses pembelajaran kooperatif tipe NHT pada materi Ikatan kimia, aktifitas belajar siswa meningkat. Siswa mulai memahami konsep ikatan kimia yang awalnya dianggap sulit. Siswa-siswa sudah mau bertanya dan menjawab pertanyaan dari guru, memberikan pendapat, aktif dan mau bekerjasama dalam kelompok diskusinya serta tidak merasa malu untuk mempresentasikan hasil diskusi kelompoknya. Akhir dari proses pembelajaran, siswa dapat menarik kesimpulan pembelajaran secara mandiri disertai penegasan dari guru. Peningkatan aktifitas belajar yang meningkat menyebabkan hasil belajar juga meningkat Hal ini sesuai dengan pendapat Kadir (2008).

Dalam penelitian ini hasil belajar siswa pada siklus I 59,3\% dan pada siklus II $77,7 \%$. Setelah proses pembelajaran selesai pada siklus I ketuntasan siswa mencapai target yang ditetapkan dengan KKM 67.

Pada siklus I ketuntasan belajar siswa, baik ketuntasan individu maupun klasikal mengalami peningkatan cukup signifikan. Dari 27 siswa yang mengikuti evaluasi terdapat $16(59,3 \%)$ siswa yang tuntas dan $11(40,7 \%)$ siswa yang tidak tuntas. Selanjutnya setelah dilakukan perbaikan pada siklus II terdapat sebanyak $21(77,7 \%)$ siswa yang tuntas dan hanya $6(22,3 \%)$ siswa yang tidak tuntas, mengalami peningkatan ketuntasan sebesar $18,4 \%$.

Ketuntasan klasikal pada siklus I hanya 59,3\%, setelah dilakukan perbaikan pada siklus II, ketuntasan klasikal siswa meningkat lagi menjadi 77,7\%, meningkat sebesar $18,4 \%$. Sedangkan daya serap siswa pada siklus I hanya sebesar 69,7\%, setelah dilakukan perbaikan pada siklus II mengalami peningkatan menjadi 74,7\%, meningkat sebesar $5 \%$.

Model pembelajaran kooperatif tipe NHT ini memberi nuansa baru dalam proses pembelajaran. Dimana pada awalnya siswa menganggap pelajaran kimia sulit menjadi tertarik dengan pemilihan model pembelajaran yang sesuai. Apalagi pada materi ikatan 
kimia yang bersifat abstrak, siswa dapat memahami dan menjelaskan sendiri proses pembentukan ikatan kimia (ikatan ion, kovalen, kovalen koordinasi dan ikatan logam) sehingga siswa dapat mengingat konsepnya yang bukan sekedar hafalan belaka.

Para ahli mengatakan, apabila aktivitas belajar siswa tinggi terhadap suatu mata pelajaran dipastikan hasilnya akan baik. Sehubungan dengan penerapan pembelajaran kooperatif tipe NHT pada materi ikatan kimia sangat tepat sekali digunakan. Sebab pembelajaran tipe NHT dapat meningkatkan hasil belajar siswa. Meningkatnya hasil belajar siswa pada materi ikatan kimia disebabkan pelaksanaan pembelajaran kooperatif melibatkan secara langsung siswa dalam proses pembelajaran. Dengan keterlibatan secara langsung siswa dalam proses pembelajaran tersebut, akan memudahkan siswa memahami materi yang disampaikan guru. Di samping itu, akan memudahkan siswa mencerna dan mengimplementasikan materi pelajaran ke dalam bentuk soal-soal yang diberikan guru.

\section{SIMPULAN}

Berdasarkan hasil penelitian dan pembahasan maka dapat disimpulkan sebagai berikut: (1) Pembelajaran kooperatif tipe NHT dapat meningkatkan aktivitas belajar kimia siswa kelas $\mathrm{X}$ semester 1 SMA N 1 Bantan pada materi ikatan kimia. (2) Pembelajaran Kooperatif tipe NHT ini dapat meningkatkan hasil belajar siswa kelas X Semester 1 SMA N 1 Bantan pada materi ikatan kimia.

\section{DAFTAR PUSTAKA}

Darsono, MA, 2002, Belajar dan Pembelajaran, IKIP Press, Semarang

Kadir A, 2008, Aktivitas dan Prestasi Belajar, http://www.ipotes.wordpress.com.

Kusuma E, Wijayati N, Wibowo LS, 2008, Pembelajaran Kooperatif Tipe NHT Berbasis Savi Untuk Meningkatkan Hasil Belajar Kimia Pokok Bahasan Laju Reaksi. Jurnal Pendidikan Kimia, 2(1)

Lie, A, 2004, Cooperative Learning Mempraktikkan Cooperative Learning di RuangRuang Kelas, Grasindo, Jakarta

Muliyati, M., Rachmawaty R., Hala Y., dan Jumadi, O., 2007, Peningkatan Motivasi, Aktivitas, dan Hasil Belajar Biologi Melalui Penerapan Model Pembelajaran 
Numbered Head Together Pada Peserta Didik Kelas XI IPA 5 SMA Negeri 1 Masamba, Journal of Biological Education, 1(1)

Rofiqoh, F., Mahardika, I. K., dan Yushardi, 2015, Pengaruh Model Pembelajaran Kooperatif tipe Numbered Heads Together (NHT) disertai Media Monopoli Games Terintegrasi Pendekatan Problem Solving pada Pembelajaran Fisika di SMA, Jurnal Pembelajaran Fisika, 4(3).

Sudarmo, U., 2006, Kimia untuk SMA kelas X, Phibeta Aneka Gama, Ciracas Jakarta

Sudjana, N., 2002, Dasar-dasar Proses Belajar Mengajar, Sinar Baru Algasindo, Bandung

Wijayatia, N., Kusumawatia I, Kushandayani, T., 2008, Penggunaan Model Pembelajaran Numbered Heads Together untuk Meningkatkan Hasil Belajar Kimia, Jurnal Inovasi Pendidikan Kimia, 2(2). 


\author{
VALIDITAS BAHAN AJAR KIMIA PADA MATERI \\ IKATAN KIMIA BERBASIS EXE-LEARNING UNTUK \\ SEKOLAH MENENGAH TINGKAT ATAS/SEDERAJAT \\ Herdini, Maria Erna* dan Restu Aminullah \\ Program Studi Pendidikan Kimia,FKIP, Universitas Riau, Riau \\ *Korespondensi: mariaerna@lecturer.unri.ac.id
}

\begin{abstract}
Chemistry teaching materials exe-learning based on chemical bonding material is designed according to the standards of competence in the curriculum of 2013. This type of research is the development of research using a model ADDIE (Analyze, Design, Development, Implement and Evaluate). The study was conducted only to the extent Development, for the purpose of this research was limited to develop and produce chemical materials exe-learning based on chemical bonding material that is valid for use in learning based on ratings validator. Data collection instruments used were sheets of expert validation of materials and sheet validation media expert who covers the designing aspect, the aspect of pedagogy, content aspect and the aspect of ease of use that is given to 4 people validator that is, one of the experts in the media and 3 experts materials and questionnaire responses of participants learners with the number of respondents 30 learners. Data analysis techniques used in this research is descriptive statistical analysis, namely by calculating the percentage of the value of the validation. Research shows that the results of the validation is done at the end of the validation activities earn a percentage of average rating of $89.14 \%$ with a valid category and the percentage of responses for $94.81 \%$ of learners in both categories. Based on the analysis of the percentage of the eligibility criteria can be concluded that chemical teaching materials based on the exe-learning material developed chemical bonds are valid for use in the X class chemistry learning Senior High School.
\end{abstract}

Key Words: ICT-based teaching materials chemistry, Exe-learning, chemical bonding 


\begin{abstract}
Abstrak
Bahan ajar kimia berbasis exe-learning pada materi ikatan kimia dirancang sesuai dengan standar kompetensi pada Kurikulum 2013. Jenis penelitian yang digunakan adalah penelitian pengembangan dengan menggunakan model ADDIE (Analyze, Design, Development, Implement and Evaluate). Penelitian dilakukan hanya sampai pada tahap Development (Pengembangan), karena tujuan penelitian ini hanya sebatas mengembangkan dan menghasilkan bahan ajar kimia berbasis exe-learning pada materi ikatan kimia yang valid untuk digunakan dalam pembelajaran berdasarkan penilaian validator. Instrumen pengumpulan data yang digunakan adalah lembar validasi ahli materi dan lembar validasi ahli media yang meliputi aspek perancangan, aspek pedagogik, aspek isi dan aspek kemudahan penggunaan yang diberikan kepada 4 orang validator yakni, 1 orang ahli media dan 3 orang ahli materi serta angket tanggapan peserta didik dengan jumlah responden 30 orang. Teknik analisis data yang digunakan dalam penelitian adalah analisis statistik deskriptif, yaitu dengan cara menghitung persentase nilai validasi. Penelitian menunjukkan bahwa hasil validasi yang dilakukan diakhir kegiatan validasi memperoleh persentase rata-rata penilaian sebesar 89,14\% dengan kategori valid dan persentase tanggapan peserta didik sebesar 94,81\% dengan kategori baik. Berdasarkan kriteria kelayakan analisis persentase dapat disimpulkan bahwa bahan ajar kimia berbasis exe-learning pada materi ikatan kimia yang dikembangkan sudah valid sehingga dapat digunakan dalam pembelajaran kimia kelas X Sekolah Menegah Atas (SMA)/derajat.
\end{abstract}

Kata kunci: Bahan ajar kimia berbasis TIK, Exe-learning, Ikatan kimia

\title{
PENDAHULUAN
}

Perkembangan Teknologi Informasi dan Komunikasi (TIK) memberi dampak besar dalam kehidupan, khususnya teknologi pembelajaran. Banyak model pembelajaran yang memanfaatkan teknologi informasi dan komunikasi dalam proses pembelajaran. Adapun salah satu metode pembelajaran yang menerapkan kemajuan teknologi dan informasi adalah e-learning (Priyambodo, 2010). E-learning sering dipahami sebagai suatu bentuk pembelajaran berbasis web yang bisa diakses dari intranet di jaringan lokal maupun internet. Menurut Hamdani (2011) e-learning merupakan suatu jenis proses belajar mengajar yang memungkinkan tersampaikannya 
bahan ajar kepada peserta didik dengan menggunakan media internet, atau media jaringan komputer lain. Salah satu program aplikasi e-learning yang baik digunakan sebagai bentuk pembelajaran berbasis web dan memungkinkan untuk tersampaikannya bahan ajar kepada peserta didik adalah dengan menggunakan aplikasi exe-learning.

Exe-learning merupakan salah satu program aplikasi opensource yang dipergunakan untuk pembuatan bahan ajar berbasis e-learning (Warjana, 2008). Bahan ajar yang disusun dengan exe-learning, tersusun secara hierarki yang mencakup topik, bagian dan unit. dan juga pada aplikasi exe-learning mampu menampilkan informasi berupa teks, grafik, suara, video atau animasi yang berkaitan dengan materi pelajaran sehingga materi yang bersifat abstrak dapat divisualisasikan. Purnomo (2007) menyatakan pembelajaran menggunakan komputer seperti program exe-learning, materi dapat disajikan dalam bentuk tutorial dan disertai soal latihan pilihan ganda, sehingga pengembangan bahan ajar berbasis exe-learning sangat cocok dan mampu untuk memvisualisasikan permasalahan yang bersifat abstrak yang banyak terdapat pada mata pelajaran kimia, utamanya materi ikatan kimia

Kimia merupakan bagian dari mata pelajaran ilmu pengetahuan alam (IPA) yang diajarkan di SMA/sederajat yang erat kaitannya dengan kehidupan sehari-hari (Depdiknas, 2008). Selain itu, ilmu kimia merupakan ilmu yang mempelajari struktur, komposisi serta reaksi antara atom, ion maupun unsur (Priyambodo, 2010). Penjelasan beberapa konsep kimia juga cenderung abstrak, maka diperlukan bahan ajar berbasis TIK yang dapat membantu pemahaman para peserta didik mengenai konsep-konsep kimia tersebut. Hal ini sejalan dengan pendapat Tanrere (2012), bahwa penyampaian materi pembelajaran yang dipadukan dengan animasi gambar dan gerakan yang menarik dapat memotivasi dan menjadikan peserta didik senang untuk belajar, karena suasana belajar menjadi lebih santai dan menyenangkan. Berdasarkan hasil observasi dan wawancara dengan beberapa guru mata pelajaran kimia di Pekanbaru yaitu SMA Negeri 5 Pekanbaru, SMA Negeri 9 Pekanbaru dan SMA Muhammadiyah 1 Pekanbaru diperoleh informasi bahwa kegiatan pembelajaran di kelas masih banyak bergantung pada buku paket dan bahan ajar cetak, dan juga sekolah menggunakan latihan soal berbasis internet, tetapi ketersediaan perangkat untuk penunjang internet di sekolah tidak memadai dan latihan soal tersebut hanya berisi penugasan serta pengerjaan soalsoal kepada peserta didik. Hal inilah yang menyebabkan penyampaian konsep-konsep 
kimia yang bersifat abstrak kepada peserta didik tidak maksimal karena tidak semua peserta didik memiliki kemampuan yang sama dalam menyerap materi yang tersedia dalam buku paket dan bahan ajar cetak, terutama peserta didik yang memiliki minat yang kecil untuk membaca. Selain itu, kimia yang bersifat abstrak tidak dapat disajikan hanya dalam bentuk bahan ajar cetak dan gambar-gambar saja karena peserta didik membutuhkan visualisasi yang jelas dari materi yang bersifat abstrak tersebut. Dari hasil observasi lapangan tersebut, maka dibutuhkan bahan ajar yang dapat memvisualisasikan materi pelajaran yang bersifat abstrak dan juga bahan ajar berbasis TIK yang dapat didistribusikan secara online maupun offline sehingga dapat mempermudah peserta didik untuk mengaksesnya. Salah satu pokok bahasan dalam ilmu kimia yaitu ikatan kimia. Ikatan kimia merupakan pokok bahasan yang cenderung bersifat abstrak.oleh sebab itu dibutuhkan visualisasi dan kreativitas tenaga pengajar, sehingga konsep yang abstrak akan menjadi lebih konkrit serta mudah dipahami, seperti dipersyaratkan pada Peraturan Pemerintah Nomor 74 Tahun 2009, Bab II bagian Kesatu Pasal 3, yakni bahwa guru harus menggunakan teknologi komunikasi dan informasi secara fungsional. Pada Peraturan Pemerintah tersebut juga dijabarkan bahwa guru harus kompeten dalam memanfaatkan teknologi pembelajaran dan mampu mengembangkan diri secara mandiri dan berkelanjutan salah satunya pengembangan bahan ajar kimia berbasis exe-learning pada materi ikatan kimia. Hal ini sejalan dengan pendapat Maria (2011) yaitu guru dapat membuat konten atau informasi pendidikan dengan menggunakan exe-learning yang mana dapat mensimulasikan fenomena yang nyata dan dapat memperbaiki pembelajaran peserta didik. Hal ini jelas untuk menggantikan pemecahan masalah dan juga menambah teknologi baru yang dapat memfasilitasi proses pembelajaran dan berkontribusi baik untuk pemahaman tentang konsep yang dipelajari.

Pengembangan bahan ajar kimia berbasis exe-learning pada materi ikatan kimia merupakan salah satu solusi permasalahan tersebut dengan cara memanfaatkan TIK untuk penyampaian materi, khususnya yang bersifat multimedia interaktif. Penelitian yang relevan dengan penelitian ini dilakukan oleh Rahayu (2014) telah melakukan penelitian pengembangan media pembelajaran menggunakan multimedia interaktif exelearning pada mata pelajaran fisika materi fluida untuk SMA kelas XI yang meyimpulkan bahwa exe-learning sangat baik untuk dimanfaatkan sebagai media pembelajaran dengan nilai validasi oleh ahli media dan ahli materi dengan rata-rata 
88,41\% dengan kategori sangat baik. Menurut Sudjana (2007) peserta didik akan lebih mudah menerima materi pelajaran jika digunakan media yang dapat diintegrasikan pada kegiatan belajar mengajar. Berdasarkan uraian di atas maka penulis tertarik untuk melakukan penelitian dengan judul: Pengembangan Bahan Ajar Kimia Berbasis ExeLearning pada Materi Ikatan Kimia untuk Kelas X SMA/MA.

\section{METODE PENELITIAN}

Penelitian dilakukan di program studi pendidikan kimia Fakultas Keguruan dan Ilmu Pendidikan (FKIP) dan uji respon peserta didik terhadap bahan ajar kimia berbasis exe-learning pada materi ikatan kimia yang telah dikembangkan kepada peserta didik SMA Negeri 9 Pekanbaru dan MAN 2 MODEL Pekanbaru.

Jenis penelitian adalah penelitian pengembangan dengan menggunakan model $A D D I E$. Lee (2004) menguraikan lima tahap prosedur model pengembangan ADDIE yang meliputi Analyze, Design, Development, Implement, and Evaluate. Menurut Punaji Setyosari (2010) rancangan sistem yang sering dipakai dalam penelitian dan pengembangan secara luas adalah model pendekatan sistem yang dirancang dan dikembangkan Dick \&Carey yaitu model ADDIE. Model ADDIE lebih bersifat generik dan dirancang khusus untuk pembelajaran berbasis multimedia, sehingga sangat cocok untuk penelitian pengembangan berbasis komputer. Pada penelitian ini dilakukan sampai tahap Development yaitu mengembangkan bahan ajar kimia berbasis exelearning pada materi ikatan kimia. Langkah-langkah pengembangan bahan ajar kimia berbasis exe-learning ini dapat dilihat pada gambar 1.

Subjek penelitian adalah penilaian dari 4 orang validator dan 30 orang peserta didik (15 orang peserta didik kelas X IPA di SMAN 9 Pekanbaru dan 15 orang peserta didik kelas X IPA di MAN 2 MODEL Pekanbaru). Objek penelitian adalah bahan ajar kimia berbasis exe-learning pada materi ikatan kimia kelas X SMA/MA yang dibuat dengan menggunakan program aplikasi exe-learning. Instrumen yang digunakan dalam penelitian ini adalah silabus pembelajaran kimia pada materi ikatan kimia, analisis materi, lembar validasi ahli materi dan ahli media beserta deskriptor penilaian, lembar tanggapan peserta didik dan bahan ajar kimia yang dikembangkan dengan program aplikasi exe-learning. 


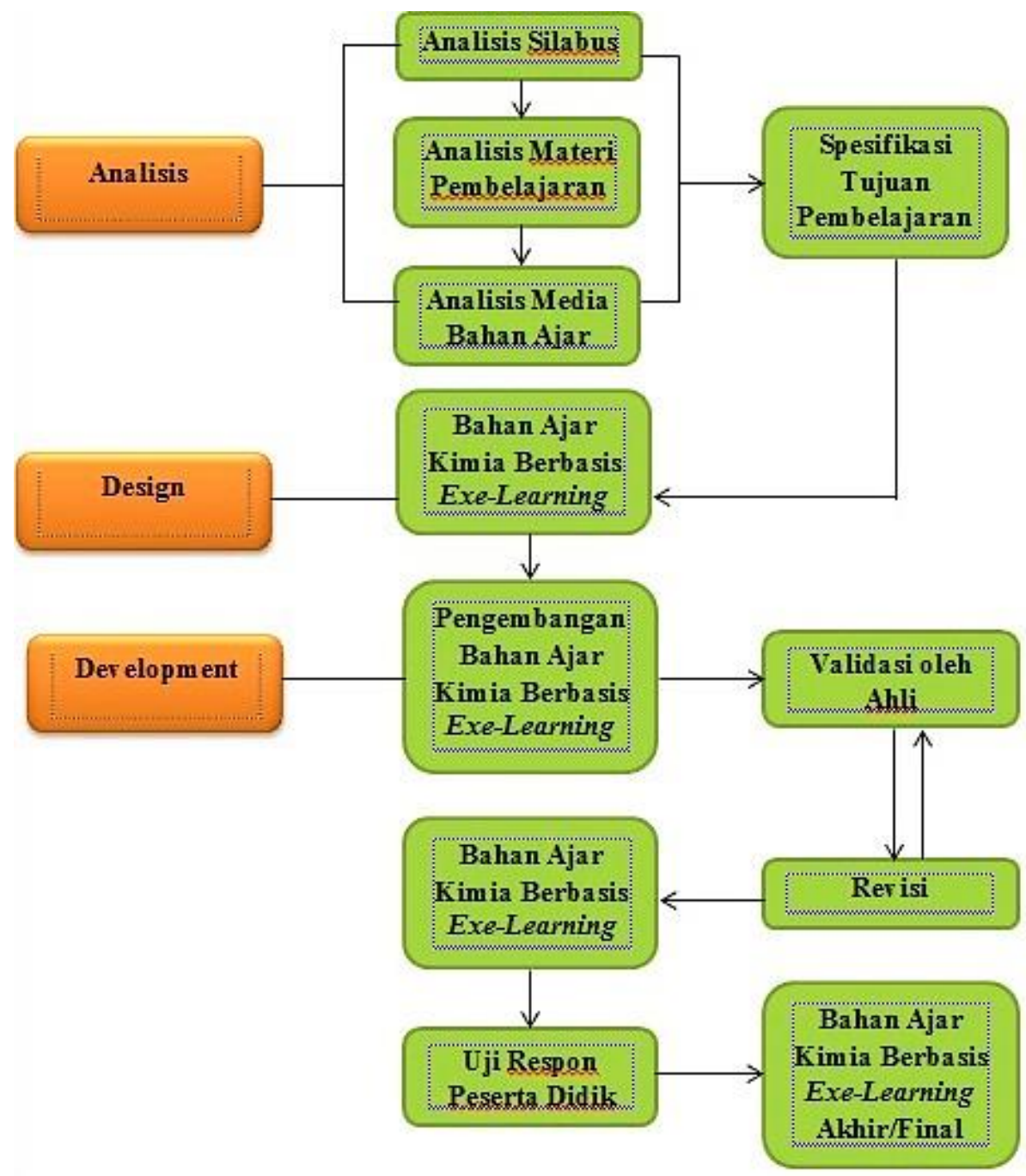

Gambar1. Diagram Alir Pengembangan Bahan Ajar Berbasis Exe-Learning Menggunakan Model ADD

Data diperoleh dari hasil pengembangan bahan ajar kimia berbasis exe-learning yang telah divalidasi oleh 4 (empat) orang validator, yang terdiri dari 2 (dua) dosen dan 2 (dua) guru kimia SMA/MA Pekanbaru serta angket tanggapan peserta didik terhadap bahan ajar kimia berbasis exe-learning terhadap 30 orang peserta didik. Uji validasi bahan ajar kimia berbasis exe-learning dilakukan oleh validator dengan menggunakan lembar validasi yang terdiri dari validitas isi yaitu penilaian aspek pedagogik dan aspek isi, baik isi media dan isi materi serta, validitas konstruk yang terdiri dari aspek perancangan dan aspek kemudahan penggunaan. Lembar validasi mengacu pada lembar validasi yang dikembangkan Nasir (2014), bahwa suatu media tersusun atas dua 
validitas, yaitu validitas isi dan validitas konstruk namun dengan modifikasi yang disesuaikan.

Validator memberikan kesan dan saran perbaikan secara umum terhadap bahan ajar kimia berbasis exe-learning yang telah dikembangkan, apakah bahan ajar kimia berbasis exe-learning pada materi ikatan kimia yang telah dibuat sudah bisa dinyatakan valid atau tidak valid melalui proses revisi terhadap bahan ajar kimia berbasis exelearning pada materi ikatan kimia.

Bahan ajar kimia berbasis exe-learning pada materi ikatan kimia yang telah dinyatakan valid selanjutnya diuji respon produk bahan ajar kimia berbasis exe-learning kepada siswa SMA/MA kelas X Pekanbaru. Uji respon produk bahan ajar kimia berbasis exe-learning pada materi ikatan kimia dilakukan dengan penyebaran lembar tanggapan peserta didik di kelas terbatas setelah memperhatikan dan menggunakan bahan ajar kimia berbasis exe-learning di kelas. Kemudian responden diminta mengisi lembar respon untuk memberikan penilaian tentang bahan ajar kimia berbasis exelearning pada materi ikatan kimia.

Teknik analisis data digunakan dalam penelitian ini adalah analisis deskriptif yakni dengan cara menghitung persentase nilai hasil validasi dan persentase nilai hasil respon produk dari peserta didik yaitu sebagai berikut:

$$
\text { Persentase }=\frac{\text { Skor yang diperoleh }}{\text { Skor Maksimum }} \times 100 \%
$$

Tabel 1. Kriteria Kelayakan Analisis Persentase

\begin{tabular}{cl}
\hline Persentase & \multicolumn{1}{c}{ Keterangan } \\
\hline $80,00-100$ & Baik/ Valid/ Layak \\
$60,00-79,99$ & Cukup Baik/Cukup Valid/Cukup Layak \\
$50,00-59,99$ & Kurang Baik/KurangValid/Kurang Layak \\
$0-49,99$ & Tidak Baik (Diganti) \\
\hline
\end{tabular}

(Riduwan, 2011)

Tingkat kelayakan produk hasil penelitian pengembangan diidentikkan dengan persentase skor. Semakin besar persentase skor hasil analisis data maka semakin baik tingkat kelayakan produk hasil penelitian pengembangan. Kriteria tingkat kelayakan analisis persentase produk hasil pengembangan dapat dilihat pada Tabel 1. 


\section{HASIL DAN PEMBAHASAN}

Penelitian ini menghasilkan suatu produk berupa bahan ajar kimia berbasis exelearning pada materi ikatan kimia untuk kelas X SMA/MA yang dikemas dalam bentuk CD (Compact Disk). Bahan Ajar kimia berbasis exe-learning telah melewati proses pemvalidasian oleh para ahli materi, ahli media dan uji respon produk terhadap bahan ajar kimia berbasis exe-learning pada materi ikatan kimia oleh peserta didik.

Pengembangan bahan ajar kimia berbasis exe-learning pada materi ikatan kimia menggunakan model ADDIE (Analyze, Design, Development, Implement and Evaluate). Penelitian pengembangan model ADDIE yang dilakukan hanya sampai tahap Development (Pengembangan), karena tujuan penelitian ini hanya sebatas mengembangkan dan menghasilkan suatu bahan ajar kimia berbasis exe-learning yang valid untuk diimplementasikan berdasarkan penilaian validator. Tahap-tahap penelitian pengembangan tersebut dijelaskan seperti dibawah ini:

a. Analysis (Analisis)

Hasil dari tahap analisis yaitu:

1) Materi pelajaran kimia yang memerlukan bantuan media yang dapat mengintegrasikan pembelajaran yaitu melalui analisis silabus dan analisis materi pembelajaran dan dipilih materi ikatan kimia. Materi ikatan kimia dipilih sebagai materi yang dibuat kedalam bahan ajar kimia berbasis exe-learning karena pada materi tersebut membutuhan hal-hal yang konkret untuk memudahkan peserta didik memahami materi seperti kestabilan atom, struktur Lewis, ikatan ion, ikatan kovalen, ikatan kovalen koordinasi, senyawa kovalen polar dan non polar, ikatan logam, gaya antar molekul, sifat fisik senyawa, dan bentuk molekul. Materi tersebut, dalam pembelajaran konvensional tidak dapat dijelaskan secara detail karena terbatasnya ruang dan waktu. Oleh karena itu, diperlukan suatu bahan ajar yang dapat mempermudah penyampaian materi pelajaran dan dapat mengarahkan pemikiran peserta didik ke ranah konkret dengan bantuan komputer.

2) Bahan ajar yang cocok diigunakan untuk materi ikatan kimia adalah bahan ajar berbasis exe-learning.

b. Design (Desain)

Hasil dari tahap desain yaitu: 
1) Rancangan awal (blueprint) bahan ajar. Hasil rancangan yang dihasilkan berupa Historyboard bahan ajar kimia berbasis exe-learning yang merupakan rancang bangun diatas kertas berisi tentang rancangan keseluruhan bahan ajar kimia berbasis exe-learning yang akan dibuat.

2) Background yang tepat serta Animasi dan video yang sesuai dan tepat dengan materi ikatan kimia yang diperoleh dengan menggunakan aplikasi Camtasia (aplikasi yang mampu merekam aktivitas yang dilakukan pada layar kerja komputer, sehingga tercipta sebuah video aktivitas layar kerja komputer).

3) Lembar validasi ahli media dan ahli materi beserta penjabaran instrumen lembar validasinya.

c. Development (Pengembangan)

Hasil dari tahap pengembangan yaitu:

1) Bahan ajar kimia berbasis exe-learning pada materi ikatan kimia untuk kelas $X$ SMA/MA.

2) Skor validasi bahan ajar kimia berbasis exe-learning.

3) Skor uji respon produk bahan ajar kimia berbasis exe-learning berdasarkan tanggapan perserta didik.

Bahan ajar kimia berbasis exe-learning yang telah dikembangkan kemudian divalidasi oleh para ahli yang menilai valid/tidaknya produk, yaitu terdiri dari 1 orang Ahli Media dan 3 orang Ahli Materi. Penilaian produk bahan ajar kimia berbasis exelearning pada materi ikatan kimia berupa validitas konstruk dan validitas isi meliputi 4 aspek yaitu aspek perancangan, aspek pedagogik, aspek isi, dan aspek kemudahan penggunaan.

Pengisian lembar validasi dilakukan diakhir kegiatan setelah melakukan 2 kali tahap validasi (kegiatan berakhir secara keseluruhan). Pada lembar validasi tersebut disediakan bagian isian untuk memberi saran, kritik, bentuk kesalahan beserta saran perbaikannya. Oleh karena itu, dari lembar validasi tersebut akan diperoleh acuan untuk melakukan revisi dan perbaikan. Hasil rekap penilaian masing-masing aspek diperoleh persentase rata-rata penilaian keempat aspek dari 4 validator yang terdiri dari ahli media dan ahli materi dapat dilihat pada Tabel 2. 
Tabel 2. Rata-rata Penilaian Keempat Aspek Pengembangan

\begin{tabular}{clcc}
\hline No & \multicolumn{1}{c}{ Jenis Aspek } & Persentase & Kategori \\
\hline 1 & Aspek Perancangan (ahli media dan ahli materi) & $88 \%$ & Valid \\
\hline 2 & Aspek Pedagogik (ahli media dan ahli materi) & $91,5 \%$ & Valid \\
\hline \multirow{2}{*}{3} & Aspek Isi (ahli media) & $80 \%$ & Valid \\
& Aspek Isi (ahli materi) & $94,22 \%$ & Valid \\
& Aspek Kemudahan Penggunaan (ahli media dan & $92 \%$ & Valid \\
\multirow{2}{*}{4} & ahli materi) & $89,14 \%$ & Valid \\
\hline
\end{tabular}

Tabel persentase penilaian keempat aspek pengembangan diperoleh bahwa skor persentase tertinggi terdapat pada penilaian validator dari aspek isi oleh ahli materi yaitu mencapai 94,22\% dengan kategori valid. Aspek isi oleh ahli materi memperoleh skor tertinggi karena dalam proses pengembangan bahan ajar kimia berbasis exe-learning ini mendapat banyak sekali masukan dan saran dari validator seperti perlu dilakukan analisis materi terlebih dahulu agar materi yang dituangkan ke dalam bahan ajar kimia berbasis exe-learning sesuai dengan standar kompetensi pencapaian indikator dan tujuan pembelajaran, serta kesesuaian penggunaan animasi dan gambar dengan konsep materi.

Bahan ajar kimia berbasis exe-learning pada materi ikatan kimia yang telah dinyatakan valid oleh validator kemudian diuji keefektifannya dengan uji respon produk bahan ajar kimia berbasis exe-learning oleh peserta didik. Tahap uji respon produk dilakukan di kelas terbatas, yaitu kelas X IPA SMA Negeri 5 Pekanbaru dan kelas X IPA MAN 2 MODEL Pekanbaru dengan jumlah responden masing-masing sebanyak 15 peserta didik. Responden yang dipilih untuk uji respon produk adalah peserta didik yang telah mempelajari materi ikatan kimia di kelas $\mathrm{X}$ semester genap sehingga peserta didik dapat memberi respon untuk menilai dan memberi saran atas bahan ajar kimia berbasis exe-learning pada materi ikatan kimia. Uji respon produk bahan ajar kimia berbasis exelearing dilakukan dengan menampilkan serta mendemonstrasikan bahan ajar kimia berbasis exe-learning pada materi ikatan kimia menggunakan infokus dan laptop, kemudian dibagikan Lembar Tanggapan Peserta Didik untuk melihat tanggapan responden tentang bahan ajar kimia berbasis exe-learning tersebut. Hasil uji respon 
produk bahan ajar kimia berbasis exe-learning oleh peserta didik mendapatkan persentase 94,81\% dengan kategori baik dan dapat dilihat pada Tabel 3.

Tabel 3. Hasil Angket Tanggapan Peserta Didik

\begin{tabular}{clccc}
\hline No & \multicolumn{1}{c}{ Indikator } & $\begin{array}{c}\text { Jumlah Item } \\
\text { Pernyataan }\end{array}$ & Persentase & Kategori \\
\hline 1 & Kualitas bahan ajar/teknologi & 3 & $94,44 \%$ & Baik \\
\hline 2 & Penyajian materi & 4 & $95,83 \%$ & Baik \\
\hline 3 & Interaksi program & 4 & $93,83 \%$ & Baik \\
\hline 4 & Desain pembelajaran & 4 & $95,16 \%$ & Baik \\
\hline & Jumlah & 15 & $94,81 \%$ & Baik \\
\hline
\end{tabular}

Bahan ajar kimia berbasis exe-learning pada materi ikatan kimia yang telah dikembangkan secara umum memperoleh penilaian yang baik dari validator dengan perolehan skor persentase untuk masing-masing aspek yaitu aspek perancangan $88 \%$, aspek pedagogik 91,5\%, aspek isi (ahli media) 80\%, aspek isi (ahli materi) 94,22\% dan aspek kemudahan pengunaan 92\% sehingga skor persentase rata-rata untuk keempat aspek pengembangan adalah $89,14 \%$. Mengacu Tabel 1 Kriteria kelayakan analisis persentase nilai $89,14 \%$ terletak pada rentang 80\%-100\% dengan kategori valid. Sedangkan tanggapan peserta didik sebagai pengguna dengan skor persentase $94,81 \%$ dengan kategori baik yang mengacu pada Tabel 1 kriteria kelayakan analisis persentase. Secara umum manfaat yang dapat diperoleh dari penggunaan bahan ajar kimia berbasis exe-learning pada materi ikatan kimia adalah proses pembelajaran menjadi lebih menarik, lebih interaktif, waktu yang digunakan selama proses pembelajaran lebih efektif, kualitas dan sikap belajar peserta didik dapat ditingkatkan dan proses pembelajaran dapat dilakukan dimana dan kapan saja.

\section{KESIMPULAN}

Berdasarkan Hasil dan Pembahasan diperoleh kesimpulan sebagai berikut: (1) persentase penilaian validator terhadap bahan ajar kimia berbasis exe-learning pada materi ikatan kimia dengan skor persentase rata-rata sebesar $89,14 \%$ dengan kategori valid; (2) persentase tanggapan peserta didik terhadap bahan ajar kimia berbasis exelearning pada materi ikatan kimia dengan skor persentase sebesar 94,81\% dengan 
kategori baik; dan (3) bahan ajar kimia berbasis exe-learning pada materi ikatan kimia yang valid dan dapat digunakan sebagai bahan ajar dalam pembelajaran kimia untuk kelas X SMA/MA.

\section{DAFTAR PUSTAKA}

Depdiknas, 2008, Panduan Pengembangan Bahan Ajar, Depdiknas, Jakarta

Hamdani, 2011, Strategi Belajar Mengajar, Pustaka Setia, Bandung

Lee, W W., dan Diana L Owen, 2004, Multimedia Based Intruktional Design, Pfeiffer, San Fransisco

Maria, E., Maria Lucia Pozzatti, Ana Marli dan Liane Margarida Rockenbach., 2011, GeoGebra and eXe Learning: applicability in the teaching of Physic and Mathematics, Journal Systemics, Cybernetics and Informatics., 9(2)

Nasir, Muhammad, 2014, Development and Evaluation of The Effectiveness of Computer-Assisted Physics Instruction, International Education Studies, 7 (13)

Priyambodo, E., 2010, Pemanfaatan Program Aplikasi Exe (ELEARNING XHTML EDITOR) dalam Penyusunan Media Pembelajaran di Sekolah, FMIPA Universitas Negeri Yogyakarta, Yogyakarta

Purnomo, W., 2007, Cara Cepat Membuat Bahan Ajar Berbasis Web, VEDC Seminar Nasional Menuju Sekolah Berbasis ICT, Malang

Rahayu, U., 2014, Pengembangan Media Pembelajaran Fisika Modul kontekstual Interaktif Berbasis Website Offline dengan penggunaan Program Exe-Learning V-1.04.0 untuk SMA Kelas XI Pokok Materi Fluida, Universitas Sebelas Maret, Surakarta

Riduwan, 2011, Skala Pengukuran Variabel-variabel Penelitian, Alfabeta, Bandung Setyosari, P., 2010, Metode Penelitian Pendidikan dalam Pengembangan, Prenada Media Group, Jakarta

Sudjana, N., dan Ahmad Rivai, 2007, Media Pengajaran, Sinar Baru, Bandung

Tanrere, M., dan Sumiati Side, 2012, Pengembangan Media Chemo-Edutainment melalui Software Macromedia Flash MX pada Pembelajaran IPA Kimia SMP. Jurnal Pendidikan dan Kebudayaan, 18(2).

Warjana dan Abdul Razaq, 2008, Membuat Bahan Ajar Berbasis Web dengan eXe, Elexmedia Komputindo, Jakarta 